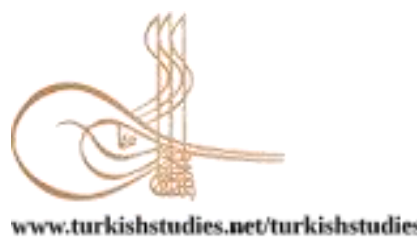

Turkish Studies

\title{
Popüler Bir Suç Dramasında Adalet: Çukur Dizisi İzleyicilerinin Adalet Anlayışları Üzerine Nicel Bir Araştırma*
}

\author{
Justice in a Popular Crime Drama: A Quantitative Research on The Justice Understanding of \\ Çukur Audiences
}

\author{
Engin Sar1 ${ }^{* *}$ - Muslu Caner Nezir***
}

\begin{abstract}
This study examines the narratives of TV dramas that commit crime and punishment around a problem of justice and evaluate the understanding of justice that viewers interpret these series. The main question of the article is: "What kind of a sense of justice do the TV audience approach the events and characters in the TV series?" In the context of this essential question, it was questioned how the audience understood and interpreted the phenomenon of crime and punishment, which is constantly committed in TV series. In the article, it is accepted that justice is relative in the context of philosophy of law. Accordingly, questions have been developed to determine the socio-economic characteristics of the audience and their understanding of justice within the framework of the relativity of justice and the social class, place, time and worldview elements. In this framework, the study was conducted by directing the questions about the series contents around this basic problematic to the audience of the most popular TV crime and action series Çukur in the last few years. In this sense, this TV viewer research is a kind of survey research called the "common observation method". This questionnaire was designed in three main axes in order to examine the relativity of the viewers' understanding of justice and how these understandings differ. According to the findings of the quantitative audience research it has been seen that the audience of the series can evaluate the issue of justice around crime and punishment from an active position, regardless of industrial or cultural coding. It is understood that audiences with different social class, gender and world views have different conceptions of justice. However, in certain situations, media culture has prevented social class, world view and gender factors in terms of directing viewer position, frameworks for meaning of media text and some thoughts about justice. At the end of the research, it can be argued that the material and symbolic dimensions and subject positions shape the
\end{abstract}

\footnotetext{
* Bu makalede, 2019 Bahar döneminde Ankara Üniversitesi Sosyal Bilimler Enstitüsü Radyo Televizyon ve Sinema Anabilim Dalında yapılan ve başarılı bulunan "TV Dizisi Seyircilerinin Adalet Anlayışları: 3 Popüler Dizinin İzleyicileri Üzerine Nicel Bir Araştırma" başlıklı yüksek lisans tezinin (Haz. Muslu Caner Nezir. Danışman Dr. Öğr. Üyesi Engin Sarı) verilerinden yararlanılmıştır.

** Dr. Öğr. Üyesi, Ankara Üniversitesi, İletişim Fakültesi, Radyo Televizyon ve Sinema Bölümü Asst. Prof. Dr. Ankara University, The Faculty of Communication (ILEF) The Department of Radio, TV and Film ORCID 0000-0002-8544-4289 esari@ankara.edu.tr

*** Doktora Öğrencisi, Ankara Üniversitesi, İletişim Fakültesi, Radyo Televizyon ve Sinema Bölümü PhD Student, Ankara University, The Faculty of Communication (ILEF) The Department of Radio, TV and Film ORCID 0000-0002-3898-8507 canernezir@yandex.com

Cite as/ Atıf: Sarı, E. \& Nezir, M. C. (2020). Popüler bir suç dramasında adalet: Çukur dizisi izleyicilerinin adalet anlayışları üzerine nicel bir araştırma. Turkish Studies, 15(5), 2589-2624. https://dx.doi.org/10.7827/TurkishStudies.44325

Received/Geliş: 18 June/Haziran 2020

Accepted/Kabul: 25 August/Ağustos 2020

Copyright $\odot$ MDE, Turkey 
understanding of the media text and the understanding of justice, as well as the structure of a more general media (TV) structure a unique style of viewing and interpretation.

\section{Structured Abstract: Introduction}

This study examines the narratives of TV dramas that commit crime and punishment around a problem of justice and evaluate the understanding of justice that viewers interpret these series. The main question of the article is: "What kind of a sense of justice do the TV audience approach the events and characters in the TV series?" In the context of this essential question, it was questioned how the audience understood and interpreted the phenomenon of crime and punishment, which is constantly committed in TV series.

\section{Purpose and Theortical Framework}

In the article, it is accepted that justice is relative in the context of philosophy of law. Accordingly, questions have been developed to determine the socio-economic characteristics of the audience and their understanding of justice within the framework of the relativity of justice and the social class, place, time and worldview elements that Anıl Çeçen has set as a kind of relativity criteria. In the paper, the social class is handled according to Pierre Bourdieu's social stratification theory, which evaluates the economic and cultural dimensions together.

\section{Method and Analysis}

In this framework, the study was conducted by directing the questions about the series contents around this basic problematic to the audience of the most popular TV crime and action series Çukur in the last few years. In this sense, this TV viewer research is a kind of survey research called the "common observation method". This questionnaire was designed in three main axes in order to examine the relativity of the viewers' understanding of justice and how these understandings differ.

These axes are: 1) whether justice should be provided within the law or illegally, 2) whether it is personal or social in terms of the responsibility of the crime, 3) whether it should be given with a sense of benefit with punishment motivation, the least harm for the criminal and the highest for the society. Over 200 different socioeconomic status viewers participated in the audience survey. The data obtained were statistically depicted by frequency analysis and cross tables, and interpreted around Stuart Hall's coding and decoding theory and philosophical approaches to crime-punishment and justice. Then, in the discussion section, these comments are examined in a way that will both respond to the main problem of the research and be linked to the active-passive audience issue in communication and media research. Hall's coding-decoding theory, adopted in the article, suggests that it is possible for the viewer to read the text in different ways. In this context, it is possible for the audience to read each media text in three different ways: Dominant/hegemonic position, negotiated position, oppositional position. Dominant position is one where the user takes the actual meaning directly, and decodes it exactly the way it was encoded by the producers. Negotiated position is a mixture of accepting and rejecting elements of a media content. Readers are acknowledging the dominant message, but are not willing to completely accept the message the way the encoder intended. According to the oppositional position a viewer can understand the literal (denotative) and connotative meanings of a message while decoding a message in a totally opposite way. This means that a person recognizes that their meaning is not the hegemonic meaning, or what was intended, but changes the message in their mind to fit an "alternative framework of reference.

\section{Findings and Results}

According to the findings of the quantitative audience research it has been seen that the audience of the series can evaluate the issue of justice around crime and punishment from an active position, regardless of industrial or cultural coding. It is understood that audiences with different social class, gender and world views have different conceptions of justice. However, in certain situations, media culture has prevented social class, world view and gender factors in terms of directing viewer position, frameworks for meaning of media text and some thoughts about justice. At the end of the research, it can be argued that the material and symbolic dimensions and subject positions shape the understanding of the media text and the understanding of justice, as well as the structure of a more general media (TV) structure a unique style of viewing and interpretation.

Based on the general results, having a higher level of economic and cultural capital on the relativity of justice, that is, being close to the middle class rather than the lower class, and the closeness of the world view 
to the left was seen with higher acceptance of some elements of the understanding of justice formed under the logic of modern law.

Keywords: Communication Sciences, Media Studies, TV Audience, Crime Drama, Justice.

Öz: Bu makalenin, suç ve cezayı işleyen TV dramalarının anlatılarının bir adalet sorunsalı etrafında ele alınabileceğinden hareketle cevabını aradığı temel soru şudur: "Dizi seyircileri dizilerdeki olaylara nasıl bir adalet anlayışı ile yaklaşmaktadır?". Bu esas soru bağlamında, dizilerde sürekli işlenen suç ve ceza olgusunu izleyicilerin nasıl bir adalet anlayışıyla anlamlandırdıkları ve yorumladıkları incelenmiştir. Bu çerçevede çalışma, bu temel problematik etrafında dizi içerikleri ile ilgili hazırlanan soruların, son birkaç yılın en popüler TV suç ve aksiyon dizisi Çukur'un izleyicilerine yöneltilmesi ile yapılmıştır. Bu anlamda bu TV izleyici araştırması, "yaygın gözlem yöntemi" diye anılan türden, bir tür tarama araştırmasıdır. Bu sormaca (anket/tarama) dizi seyircilerinin adalet anlayışlarının göreliliği ve bu anlayışların ne şekilde farklılaştığını dizi okumaları üzerinden inceleyebilmek için üç ana eksende tasarlanmıştır. Bu eksenler şunlardır: 1) adaletin hukuk içi mi, yoksa hukuk dışı mı sağlanması gerektiği, 2) suçun sorumluluğu bakımından kişisel mi yoksa toplumsal mı olduğu 3) cezaların öç almacı bir motivasyon ile mi, yoksa suçlu için en az zarar ve toplum için en yüksek fayda anlayışı ile mi verilmesi gerektiği. Tarama çalışmasına 200'ün üzerinde farklı sosyoekonomik statüye sahip izleyici katılmıştır. Elde edilen veriler, sıklık analizi ve çapraz tablolar ile istatistiki olarak betimlenmiş ve Stuart Hall'ün kodlama ve kodaçımlama teorisi ve suç ve ceza konusundaki felsefi yaklaşımlar etrafında yorumlanmıştır. Ardından tartışma bölümünde bu yorumlar hem araştırmanın temel problemine yanıt üretecek hem de iletişim ve medya araştırmalarındaki etken-edilgen izleyici meselesiyle bağlantılandırılacak tarzda irdelenmiştir. Nihai olarak, dizi izleyicilerinin, suç ve ceza olgusu bağlamında adalet konusunu, endüstriyel ya da kültürel kodlamalar ne olursa olsun, etkin bir konumdan değerlendirebildikleri görülmüștür. Farklı sınıf, toplumsal cinsiyet ve dünya görüşüne sahip izleyicilerin, farklı adalet kavrayışları olduğu anlaşılmaktadır. Ancak belli durumlarda medya kültürü, izleyici konumunu, medya metnini anlamlandırma çerçevelerini ve adalete dair bazı düşünceleri yönlendirmek bakımından, sınıf, dünya görüşü ve cinsiyet etkenlerinin önüne geçmiştir. Araştırma sonunda maddi ve sembolik boyutlarıyla özne konumlarının, medya metnini anlamlandırmayı ve adalet anlayışını biçimlendirdiği, ayrıca daha genel bir medya (TV) kültürünün özgün bir izleme ve yorumlama tarzını yapılandırdığı iddia edilebilir.

Anahtar Kelimeler: İletişim Bilimleri, Medya Araştırmaları, TV İzleyicisi, Suç Draması, Adalet

\section{Giriş}

Türkiye'de televizyonun, televizyon dizilerinin ya da dramalarının ${ }^{1}$ gündelik ve kültürel hayatımızda ağırlıklı bir yeri olduğunu anlamak için bir gün televizyon karşısında oturmak, sıradan bir sosyalleşmede bir diziden, hikâyeden, karakterden sohbet açmak yeterli olur. Erol Mutlu (1991: 10) "içimizden biri" ve "ailemizin üyesi" olarak adlandırdığı televizyonun sosyal ve kültürel yaşamımızın sanılandan daha fazla içinde olduğunu vurgular. Orhan Tekelioğlu da televizyonun "Zaman zaman izlediğimiz zaman zaman sadece baktığımız ama her daim karşısında konumlandığımız, evin eşyalarının bile kendisine çevrildiği bir merkez" olduğuna dikkat çeker (2017: kapak). Televizyonun bu kültürel ağırlığını Henri Lefebvre'nin otomobil için kullandığı "kral nesne" ve "kılavuz şey" kavramları ile de düşünebiliriz. Lefebvre (2007: 115) modern yaşamın "kral nesnesi" olarak gördüğü otomobili, kent hayatını belirleyen, şehrin düzeninin kendisine göre kurulduğu, kısacası kamusal mekânı organize eden bir araç olarak sunar. Ev içindeki düzeni

\footnotetext{
${ }^{1}$ Televizyon dramalarının üç alt türü vardır: 1) her bölümünde ayrı bir olay örgüsüne sahip olan, tek bir bölümde başlayıp biterek kapanan parçalardan (episode) oluşan "diziler", 2) bütünlüklü bir hikayesi olan ve bunun (genelde haftalık) bölümlere yayılarak aktarıldığı "seriyaller", 3) bütün bir hikayenin çok daha uzun zaman dilimlerine, örneğin yıllara yayıldığı, yeni karakterlerin katılımı ya da mevcutların çıkmasıyla devam eden "süren seriyaller" (Özsoy, 2011: 130) (Çelenk, 2005: 290). Türkiye'de üretilen televizyon dramalarının çoğu, seriyal veya süren seriyal formatında hazırlanmaktadır. Bununla birlikte, bilimsel tasnifler bir yana, popüler ve gündelik kullanımda tv dramaları "dizi" olarak anılmaktadır. Türkiye'de televizyon dramaları konusunda yapılan çok sayıda çalışmada olduğu gibi, bu makalede çoğunlukla "dizi" terimi tercih edilmektedir.
} 
belirleyen ve ailenin bir üyesi olan televizyon da özel alanın hatta bir ölçüde kamusal alanın da "kral nesnesi" sayılabilir. Klaus B. Jensen, yapisalc1 antropolog Levi Strauss'un totemizmde hayvanların, kendileri aracılığıyla anlamlar inşa edilen ve yaşamın kendileri vasıtasıyla düşünüldüğü simge canlılar olduklarını açıklarken kullandığı "düşünmek için iyi" ifadesinden esinlenerek, medya için bir kavram kullanır: "düşünmek için kurumlar" (İng. "instutiton to think with"). Bu kullanımla işaret ettiği, medya kurumlarının ekonomik örgütlenmeler olmakla birlikte, anlamı üreten ve yayan yapılar olmaları nedeniyle, toplumsal ölçekte düşünümselliği mümkün kılan kurumlar olduklarıdır (Jensen, 2002: 6-7). Bu perspektife göre medyayı ve özellikle televizyonu, kendileri aracılığıyla düşünülen, toplumsal anlamların inşa edildiği ve dolayımlandığı kurum şeklinde tanımlayabiliriz. Televizyon, hane içinin kral nesnesi, kamusal alanla da yapısal ilişki içinde olan, anlam inşa ve dolaşım süreçlerinin tam ortasında, vazgeçilmez bir araçtır. Yeni medya çağının karmaşık, mecraların iç içe geçtiği, yöndeştiği iletişim ortamında da önemini yitirmemiştir. Televizyon bu yeni ortama uyumlanarak ve çapraz kullanımlar ile daha geniş bir alana nüfuz etme imkânına kavuşarak başatlığını, bir anlamda "krallığını" sürdürmektedir.

Televizyondaki program türleri arasında ise dizilerin önemli bir yeri vardır. Türkiye'de özel TV yayıncılığının başladığı 1990'lı yıllardan itibaren, çok kanallı yayıncılıkta da "başarılı" olan televizyon dramalarının ticari ve kültürel önemi giderek artmıştır. (Çelenk, 2005: 291) (Tanrı̈̈ver, 2012: 47-48). Günümüzde de izlenme oranlarından, oyuncularının ünlenerek "yıldız" olmaları ve kamusal karakterlere dönüşmelerinden de anlaşılacağı üzere, televizyon dramaları toplumsallığımız içindeki ağırlığını sürdürmektedir.

RTÜK'ün Televizyon İzleme Eğilimleri Araştırması'na göre (2018), televizyon izleyicilerinin en fazla takip ettiği ikinci program dizilerdir. Araştırma, televizyon izleyicilerinin aylık ortalama gün sayısı bakımından en çok takip ettikleri program türünün, öncelikli olarak ayda 24 gün ile haberler, ikinci olarak da ayda 15 gün ile yerli diziler olduğunu göstermektedir (RTÜK, 2018: 14).

Türkiye'de, son yıllarda yayınlanan televizyon dizilerinin hikâyeleri hakkında yapılacak genel ve kaba bir gözlemle bile, önemli bir bölümünde şiddet ve suç unsurlarının yer aldığını görmek zor değildir. Dizilerde dikkat çeken bu unsurlar, şüphesiz süregiden bir çatışma ve bir mücadele anlatısı içinde yer almaktadır. Şiddet, suç ve sosyal/kişisel çatışmaların iç içe kurulduğu bu dramaların anlatılarının aslında bir "adalet" meselesi etrafında örüldüğünü söyleyebiliriz. Ancak dizilerde, hangi hikâye ve temsillerin yer aldığını tespit etmek, Türkiye'deki dizi kültürünü dar bir perspektif içinden değerlendirmek olur. Türkiye televizyonlarını her akşam dolduran dizilerde izlenen hikâyelerin adalet meselesini merkeze alarak yazıldığı ve üretildiği tespitiyle yetinmek, dizi kültürünün önemli bir boyutunu dışarıda bırakır: izleyici. Bu makale, dizi izleyicilerinin, bu suç dizilerini ne tür bir adalet anlayışıyla izlediğini ve dizilerdeki adaleti nasıl yorumladığını incelemektedir. Bir başka deyişle dizilerin hikâye ve karakterlerinin bir adalet sorunsalı etrafında ele alınabileceğinden hareketle yanıtı aranan esas soru şudur: "Dizi izleyicileri dizilerde gösterilen olaylara nasıl bir adalet anlayışıyla yaklaşmaktadır?" Bu temel soru bağlamında, izleyicilerin dizilerde sürekli işlenen suç ve cezayı, nasıl bir adalet anlayışıyla seyrettikleri, yorumladıkları ve anlamlandırdıkları ortaya konmak istenmiştir.

$\mathrm{Bu}$ temel araştırma sorusunu cevaplayabilmek için, son dönemlerin en popüler suç ve aksiyon dizisi olan Çukur örnek TV dizisi olarak seçilmiş, bu dizinin izleyicilerine yönelik olarak görgül bir araştırma tasarlanmış, veriler toplanmış ve analiz edilmiştir. Araştırma kapsamında Çukur dizisi içerikleri ile ilgili hazırlanan sorular, dizinin izleyicilerine yöneltilmiştir. Bu anlamda bu TV izleyici araştırması, "yaygın gözlem yöntemi" diye anılan türden, bir tür tarama araştırmasıdır. Bu anlamda araştırma esas olarak nicel bir metodolojik yaklaşıma dayanmaktadır. Bu yaklaşım içinde, araştırma açısından en kritik konu adalet kavramının ya da soyutlamasının, gözlenebilir, ölçülebilir, yöntembilim terminolojisi içinde söylemek gerekirse işlemselleştirilmesi ya da 
operasyonelleştirilmesidir. $\mathrm{Bu}$ işlemselleştirme için, dizi hikâyeleri ve karakterleri üzerinden izleyicilerin somut durumlarla ilgili yorum ve değerlendirmeleri, sormaca formları aracıllğıyla alınmaya çalışılmıştır. İzleyicilerin adalet anlayışını açığa çıkarabilmek ve bu anlayışların ne şekilde farklılaştı̆̆ını dizi okumaları üzerinden inceleyebilmek için üç ana eksen belirlenmiştir. Bu eksenler şöyle sıralanabilir: 1) adaletin hukuk içi mi, yoksa hukuk dışı mı sağlanması gerektiği, 2) suçun sorumluluğu bakımından kişisel mi yoksa toplumsal mı olduğu 3) cezaların öç almacı bir motivasyon ile mi, yoksa suçlu için en az zarar ve toplum için en yüksek fayda anlayışı ile mi verilmesi gerektiği. Tarama çalışmasına 200'ün üzerinde farklı sosyoekonomik statüye sahip izleyici katılmıştır. Elde edilen veriler, sıklık analizi ve çapraz tablolar ile istatistiki olarak betimlenmiş ve Stuart Hall'ün kodlama ve kodaçımlama teorisi ve suç ve ceza konusundaki felsefi yaklaşımlar etrafında yorumlanmıştır. Suç ve ceza konusundaki felsefesi yaklaşımlar ise iki temel tartışma etrafında kurgulanmıştır. Bunların ilki, Anıl Çeçen'in adaletin göreliliği hakkında kuramsal tartışmasıdır. Burada adaletin mutlak ve tartışmasız bir hakikat ile ilişkili olmadığı, toplumsal ve siyasal olarak değiştiği, özetle toplumsal konumlar bakımından görelileştiği argümanı geliştirilmektedir. İkinci olarak suç ve ceza kavramları ve bunların ilişkisi, hukuk felsefesi ve Dostoyevski'nin ünlü romanı Suç ve Ceza etrafında geliştirilen kavramsal tartışma çerçevesi içinde ele alınmaktadır. Bu kuramsal değerlendirmelerin sonunda, suç ve cezanın toplumsal olarak tanımlandığı, iki olgu arasındaki ilişkinin de politik olarak kurulduğu öne sürülmektedir. Bu kuramsal değerlendirmelerden sonra araştırmanın bulguları, izleyici yorumları, betimlenmekte ve bunlar hem araştırmanın temel problemine yanıt üretecek hem de iletişim ve medya araştırmalarındaki etken-edilgen izleyici meselesiyle bağlantılandırılacak tarzda çözümlenmektedir. Bu çözümle, adaletin göreliliğini, suç ceza ilişkisinin toplumsal ve politik olarak kurulduğuna işaret etmektedir.

\section{TV Dramaları, İzleyiciler ve Alımlama Üzerine}

Mustafa Sönmez'in da belirttiği ve gözlenip tahmin edebileceği üzere televizyonların en çok izlenen zaman dilimlerinin (prime time) hemen hemen tamamını yerli diziler oluşturmaktadır. Dolayısıyla en büyük gelir kaynakları reklam yayını olan TV kanallarının kazançlarının büyük kısmı da Sönmez' in rakamlarına göre \%80 oranında yerli dizi yayınına dayanmaktadır (Sönmez, 2010: 80).

Türkiye'de dizi endüstrisi özellikle 2000'lerden itibaren çok büyük bir hızla büyümüştür. Türkiye'de her yıl yüzün üzerinde dizi üretilmektedir. Üretilen her 4 diziden 3'ü ise yüzü aşkın ülkeye ihraç edilmektedir. Öncelikle Ortadoğu, Balkan ve Arap ülkeleri olmak üzere, Şili, Ekvator gibi Latin Amerika ülkeleri ve Çin, Rusya, Pakistan gibi Asya ülkelerine pazarlanan Türkiye yapımı dizilerin tüm dünyada 400 milyonu aşan bir izleyiciye ulaştığı öngörülmektedir (Öztürk \& Atik, 2016). Türkiye'de TV dizi endüstrisi ve ekonomisine dair sistematik bir veri üretimi ya da istatistiki çalışma olmamakla birlikte dizi ihracaatı hakkında Kültür ve Turizm Bakanlığın açıkladığı rakamlar vardır. Kültür ve Turizm Bakanı Mehmet Nuri Aksoy’un açıklamasına göre Türk TV Dizi sektörüne aktarılan devlet desteği ile ihracat rakamları 2019 yılında 350 milyon dolara ulaşmış, en yüksek izlenme oranları Avrupa ülkelerinde olmuştur. Bu ihracaat rakamları ile tüm dünyadaki TV içerik ticaretinin yüzde 25 'ni Türk yapımlar oluşturmuştur. ${ }^{2}$

$\mathrm{Bu}$ endüstriyel ve üretim boyutunun yanında TV dramalarına kültürel içerik ya da tema olarak baktığımızda, dizilerin hem sözlü ya da yazılı edebiyat ve geleneklerden, hem de modern anlat1 formlarından beslendiğini görürüz. Sonia Livingstone ve Tamar Liebes, Avrupa televizyonlarıda yayınlanan diziler üzerine yaptığı analiz sonucunda dramalarda öykü ve tema bakımından üç ana model saptar. Birinci model, hanedanlık modelidir ve güç/iktidar meseleleri, merkezdeki bir aile, bu ailenin çevresindeki ötekiler ve onlarla (aşk, evlilik vb. yollarla) ilişkilerini konu alır. İkinci model, topluluk yaşamına yoğunlaşır ve hem sınıfsal hem de yaş-kuşak çeşitliliğiyle

\footnotetext{
${ }^{2}$ https://www.aa.com.tr/tr/kultur-sanat/turkiye-dizi-film-ihracatinda-hollywooda-rakip-oldu/1408437 Erişim: 03.04.2020. Ayrıca dizi sektörüyle ilgili kesin ve özgül veriler içermemekle birlikte TÜİK'in görsel-işitsel ithalat-ihracat istatistikleri de yayınlanmaktadır.
} 
karakter bakımından zengindir. Topluluk modelinde, idealize edilmiş bir birliktelik hali sunulur ve kısmen nostaljik göndermeler içerse de günlük rutinler ve çatışmalar işlenir. Üçüncü model moleküler ilişkileri işleyen modeldir ve çok sayıda genç karakterin istikrarsız ilişkileri ele alınır. Moleküler modelde, karakterlerin duygusal bağlarına, romantik ilişkilerine ya da akrabalık ilişskilerine yoğunlaşılır (Liebes \& Livingstone, 1998). Livingstone ve Liebes'in modelinin açıklama gücünün, televizyonun 2000'lerden sonra küreselleşmenin de ivmesiyle hem bir endüstri hem de bir kültürel anlatı olarak geçirdiği hızlı dönüşüm neticesinde zayıfladığı söylenebilir ancak modeldeki temaların, günümüz dizilerinde farklı kombinasyonlar ve melezleşmelerle yer almaya devam ettiğini de belirtmek gerekir.

Türkiye'nin dizi tarihine kabaca baktığımız zaman da Livingstone ve Liebes'in andığı temaların çeşitli biçim ve birleşimlerle bir araya getirildiğini, geleneksel ve modern öykü ve temaların iç içe geçirildiğini görürüz. Sevgi Can Yağcı Aksel, 1990'ların ortalarından itibaren dev bir sektöre dönüşmeye başlayan Türk TV Dizi yapım ve yayıncılığında, tematik olarak politik konulardan kaçınıldığını belirtir. TRT tekelinin olduğu televizyon yayıncılığı döneminde edebiyat uyarlamalarına ağırlık verilirken, özel yayıncılık döneminin başlamasıyla, karakterden çok tiplemelerin öne çıktığı güldürü türü rağbet görmüştür. 2000'lere kadar dikkat çeken tematik bir başka unsur, ailenin dizilerde merkezi yeri ve yüceltilmesidir (Yağc1 Aksel, 2011: 34). 2000'lerde ise edebiyat uyarlamalarına dönüş olur ve birkaç örnekle de olsa siyasi temalar işlenmeye başlar (Çelenk, 2010). Yine 2000'lerden itibaren yükselen bir başka tür, polisiyelerdir. Polisiye türü birden fazla sezon sürer ve sadece en çok izlenen akşam saatlerinde değil gündüz kuşağında da yayınlanmaya başlar. 2000'lerin ortasında itibaren televizyon dizilerinde görülmeye başlayan bir temalar ise, feodal değerler ve dini motifler olur (Yağc1 Aksel, 2011: 37). Son yıllarda Türk televizyonlarda yayınlanan TV dizilerinin tematik yönelimine genel olarak baktığımızda ise, özellikle Osmanlı dönemini konu alan tarihi dizilerin öne çıktı̆̆ görülmektedir. Yine bir dönem, doğrudan ve dolaylı olarak güncel politikaları konu alan diziler rağbet görmüştür. Bunlarla birlikte Tayfun Atay, izleyici ilgisini çeken TV dizilerinin ülkenin yakıcı toplumsal gerçeğinden çıkan köyden kente göç, geleneksellik -modernlik, kırsallık-kentsellik, feodallik-burjuvalık gibi ikiliklerimiz üzerinden kurgulanan diziler olduğunu söyler. Sınıfsal ve toplumsal çatışmaları, kültürel yollarla işleyen TV dizileridir bunlar (Atay, 2017). Bunlarla birlikte televizyon dizilerinde, dönem dönem belli temalar hakim olsa, tekrarlanan hikaye ve karakterler görünse de, belli oranda yeniliklere de ihtiyaç duyulur. Çünkü esas amaç izleyiciyi ekran karşısında olabildiğince fazla tutmaktır. Bunun için üretici ve yayıncılar izleyicinin, hikayelerden ve gösterilenlerden bıkmamasını ister. Televizyon endüstrisi bu yüzden, izleyicinin beklentilerini karşılamaya çalışmakla, izleyici şaşırtmak, eğlendirmek için yeni yollar bulmak arasında bir denge tutturmaya çalışır. Dizi tema ve türleri açısından, çeşitillik, yenilik, farklılık ve devamlılık arasındaki hassas denge, diziler açısından üretim ve yayın mekanizmasının temelini oluşturur (Akçay Gültekin, 2011: 58-59). Bu yüzden, diziler özellikle internet temelli ve izleyici talebine bağlı (video on demand) yayıncılığın da gelişimiyle, giderek hem teknik hem de tema olarak çeşitlenmiştir ve bu eğilim güçlenerek devam etmektedir.

TV dizi kültürünün endüstri ve içerik kadar, hatta belki de onlardan daha önemli boyutu, izleyicilerdir. Çünkü aslında hem endüstri hem de içerikler, izleyici ilgisini kazanmak için vardır. Bu varoluşsal önemine karşı, izleyici boyutu hem yönetimsel hem de akademik araştırmalar bakımından, diğer iki uğrağa oranla çok az ilgilenilmiştir. Batı akademisi içinde ağırlıklı olarak anaakım olmakla birlikte bir izleyici araştırmalarının geleneğinden söz edilebilse de Türkiye'de izleyici ile ilgilenen iletişim ve medya araştırmaları literatürü oldukça sınırlıdır. Türkiye'de dizi izleyicileri üzerine yapılmış az sayıda çalışma olduğunu ve bunların önemli bir kısmının "etki" çalışması olduğunu yukarıda belirtmiştik. Bu tür çalışmaların dışında izleyicileri, pasif birer algılayıcı olarak görmek yerine onların anlam üretiminin aktif katılımcısı olduğunu kabul ederek yapılan çalışmalar da vardır. Aydan Özsoy (2011) ve Vahit İlhan'ın (2010) çalışmaları, bu tür çalışmalara örnek olarak 
gösterilebilir. Özsoy, popüler bir durum komedisi ve bir polisiye dizi üzerine yaptığı çalışmada izleyicinin etkin konumunu, sınırlarını da kabul ederek ortaya koymuştur. İlhan da aynı şekilde, genç izleyicilerin televizyon dizilerini izleme pratikleri üzerine yaptığı çalışmada gücün yalnızca tek bir toplumsal iktidar merkezine ait olmadığı anlayışına dayanarak, medya metinlerini üretenler karşısında izleyicilerin de metinlerle karşılaştıkları noktada anlam üretimine etkin olarak katılabilen özneler olduğunu, sınırlarının farkında olmak kaydıyla kabul eder. Genç izleyicilerin ailevi, sosyoekonomik durumları ve arkadaş çevresi gibi etkenlerin, diziler karşısındaki anlam çerçevelerini farklılaştıran önemli unsurlar olduğunu ortaya koyar (İlhan, 2010)

İlhan, 1990'l1 yıllardan itibaren, özel yayıncı kuruluşların faaliyete başlamasıyla birlikte Türkiye'de öncelikle yabancı televizyon dramalarının yoğun olarak yayınlandığını, zaman içinde yerli dramaların yapıldığını ve 2000'li yıllara girerken yerli dizilerin hakimiyetinin görüldüğünü belirtir. Yerli dizilere olan rağbetin artmasıyla, 2010 yılından itibaren dizilerin, televizyon kanallarının en önemli izlenme nedeni haline geldiğini söyler (2010: 119-120). İlhan, çeşitli kuruluşların yaptığı araştırmalara atıfla Türkiye'de en çok izlenen televizyon kanallarının aynı zamanda dizileri seyretmek için en çok tercih edilen kanallar olduğuna, izleyicilerin önemli bir oranda yalnızca dizileri izlemek için televizyon kullandığına ve dizilerin televizyon program türleri arasında en çok izlenen türlerden biri olduğuna değinir (2010: 121-123). Bu durum, dizi izleme pratiğinin, televizyon yayıncılığının en önemli bileşenlerden biri olduğunu gösterir. İzleyiciler ve izlenme, televizyon yayıncılığı ve dizi endüstrisi açısından belirleyici bir olgu olmakla birlikte, hem medya endüstri hem de akademi tarafından yeterli titizlikle ele alındığını söylemek güçtür. Türkiye'de izleme ölçümlerinin bile yeterli ve rasyonel bir sistematik ve mekanizmayla yapıldığı söylenemez.

Türkiye'de televizyon ve diziler hakkında son zamanlarda birçok araştırma yapılmıştır ancak çoğunun toplumsal cinsiyet, etnisite ve diğer kimliklerle ilgili temsil incelemesi olduğu söylenebilir. İzleyici üzerine yapılan çalışmaların ise çoğunluğunun bir tür "etki" araştırması olduğu, açıkçası aslında medyanın izleyicisine ne yaptığına yönelik gerçekleştirilen, erken dönem Amerikan iletişim araştırmalarının kabulleri temelinde yapılmış çalışmalar olduğu gözlenmiştir. ${ }^{3}$

Kitle iletişim ve medya çalışmaları alanında izleyici hakkındaki düşünceler ve tartışmalar, iletişim araştırmalarının yapılmaya başlandığı tarihe kadar geriye gider. Kitle toplumu kavramsallaştırmasıyla başlatabileceğimiz bu tartışmalar, genel olarak seyircinin edilgen veya etken olduğu önvarsayımları ve argümanları etrafında yapılmıştır. İzleyici ya da izler kitle hakkındaki ilk fikirler "pasif" izleyicinin, medya "etkilerine" fazlasıyla açık olduğunu kabul etmiştir. Daha sonraları ise yaklaşımlar, medyayı bireysel ihtiyaç ve doyumlarına göre kullanan, buradan da yine medyayı çok daha karmaşık toplumsal ve kültürel bağlamlar içinden okuyan (alımlama) bir izleyici anlayışına yönelmişsir (Roscoe, Harriette, \& Gleeson, 2005). Medya araştırmaları tarihindeki izleyici kavrayışında bahsedilen ilk aşama, "etki paradigması" olarak bilinen ABD kökenli iletişim çalışmalarına denk düşer. İkinci safha, yani izleyiciyi kendi ihtiyaç, beklenti ve talepleri çerçevesinde "etkin bir özne" olarak kabul eden yaklaşım, önemli bir dönemeçtir. Bu dönüm noktasını, Elihu Katz'ın çalışmalarını temel alan "Kullanımlar ve Doyumlar" kuramı oluşturur. Bu dönüşümle birlikte, kamusal ya da kitle iletişim süreçlerinde güç/iktidar, beyaz ekrandan alınarak etkin bir anlamlandırma eylemini gerçekleştiren seyirciye aktarılmıştır (Lewis, 2010: 351). İletişim araştırmaları içindeki izleyici tartışmalarına dair üçüncü aşama, kültürel çalışmalar geleneği tarafından biçimlendirilir. 1968-1979 yılları arasında Birmingham Çağdaş Kültürel Araştırmalar

\footnotetext{
3 İletişim ve medya çalışmaları alanında Medyanın izleyici üzerindeki etkilerine dair, yapılmış son dönemdeki araştırmalara bazı örnekler: Muhammed Yusuf(2014). Arap Topluluklarında Türk Televizyon Dizilerinin Yeri ve Önemi (Yüksek Lisans Tezi - İstanbul Üniversitesi Sosyal Bilimler Ens. RTS Anabilim Dalı). Şebnem Kadıŏlu (2010). Pembe Dizilerin Kadınlar Üzerindeki Etkisi (Yüksek Lisans Tezi - Gazi Üniversitesi Sosyal Bilimler Ens. RTS Anabilim Dalı).Ümmühan Y1lmaz (2013). TV Dizilerinin Gençler Üzerinde Tüketim Kültürü Oluşturma Süreci ve Yaşam Tarzına Etkileri (Yüksek Lisans Tezi - İstanbul Arel Üniversitesi Sosyal Bilimler Ens. Medya ve Kültürel Çalışmalar).
} 
Merkezi'nin yöneticiliğini üstlenmiş, geleneğin simge temsilcisi Stuart Hall'ün 1973 yılında "Televizyon Söyleminde Kodlama ve Kodaçımı" (Encoding and Decoding in the Television Discourse) adıyla yayınlanan makalesi, bu toplumsal, karmaşık ve etkin izleyici kavrayışının gelişebilmesine imkan veren teorik bir temel oluşturmuştur.

Hall (2005), "Kodlama ve Kodaçımı" makalesinde "kodlama" kavramıyla medya içerikleri ve metinlerinin medya kuruluşları ve profesyonellerince oluşturulma sürecini; "kodaçımı" ile de medya izleyicisinin bu metinleri alımlama ve "okuma" eylemlerini ifade eder. Kodlama sürecinin, toplumda hakim olan bazı kodların ve söylemlerin içinden biçimlenen bir süreç olmasından dolayı, izleyicinin okuma çerçevesini kısmen oluşturduğunu varsayar. Fakat bu, izleyicinin metni okurken, etkin bir şekilde anlam inşa etmesini de imkânsız kılmaz. Hall, metinlerin kodlanması ne tarzda olursa olsun, yani medya içeriklerinde üreticilerin izleyiciler tarafından alınmasını istedikleri ve bekledikleri anlam ne olursa olsun, izleyicinin metni farklı biçimlerde okuma imkânının, mümkün olduğunu kabul eder. İzleyici okumaları, çeşitli oranlarda ve tarzlarda sınırlandırılmış olabilir ama her hâlükârda bir özgünlük olasıdır. Bu doğrultuda Hall'e göre, seyircinin (okurun) her türlü medya metnini üç farklı biçimde okuması yani üç farklı izleyici konumu mümkündür: 1. Egemen (hâkim/yeğlenen) okuma, 2. Tartışmacı (müzakereci) okuma, 3. Muhalif (karşıt) okuma.

\begin{abstract}
"Birincisi, doğal, meşru, kaçınılmaz, bir toplumsal düzenin ve bir meslek evreninin anlayış biçimi gibi görünen hegemonik bakış açısına uygun düşer. İkincisi, iletiyi bir başka izafiyet çerçevesine, karşıt bir dünya görüşüne göre (örneğin ulusal çıkarı, sınıf çıkarına çevirerek) yorumlar. Tartışmacı kod ise kısmen egemen anlamları ve değerleri benimseyen, ancak yaşanan bir durumdan, örneğin ait olunan grupla ilgili çıkarlardan genellikle paylaşılan tanımlamalara karşı çürütücü tezler çıkaran karşıt mantıkların bir karması, karşıtlık ve uyum öğelerinin bir karışımıdır.” (Mattelart \& Mattelart, 1998: 87$88)$.
\end{abstract}

Özetlenerek tanımlanan bu üç okuma biçiminden ilki olan egemen veya hakim okuma, izleyicinin medya metnini, üretenlerin arzuladıkları yani kodladıkları anlamsal çerçeve içinde ele almasıdır, medya içeriklerini hazırlayanların tercih ettikleri, izleyiciden bekledikleri (yeğlenen) okuma tarzı budur.

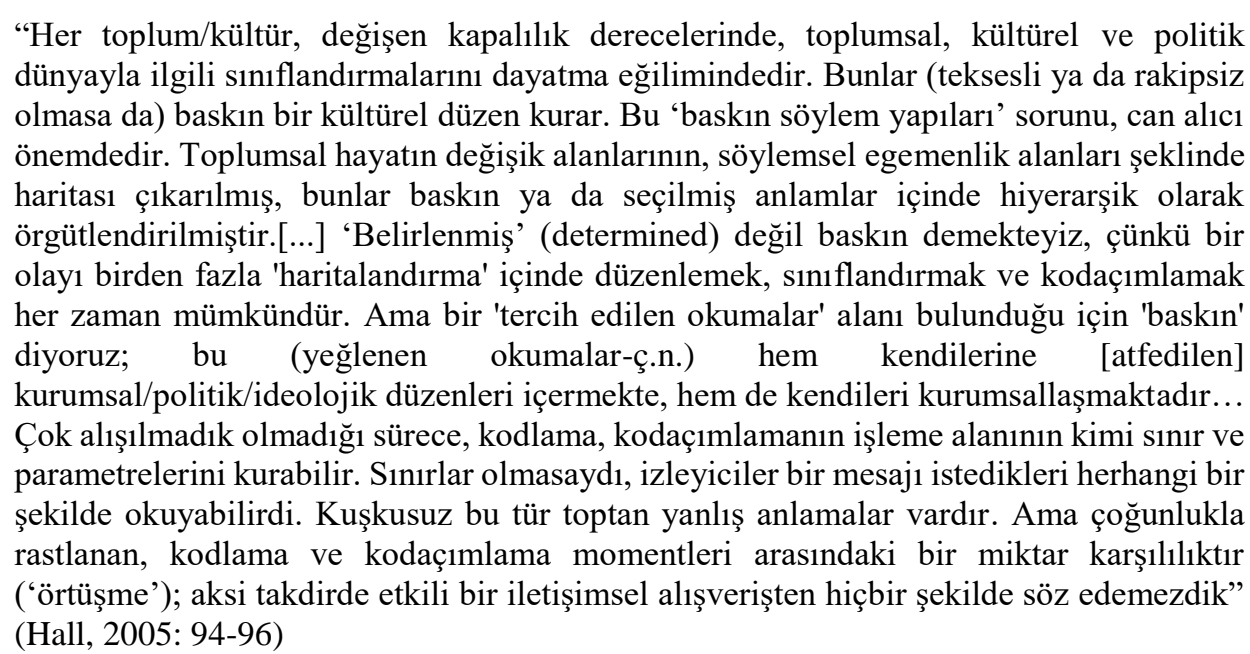

Görüldüğü gibi, Hall'e göre hakim okuma tarzı, kodlama aşamasının kısmen sınırlandırdığı ve belirlediği anlamlar etrafında işler. Müzakereci (tartışmacı) okuma, üreticiler yani kodlamayı yapanlarca alınması tercih edilen anlamlar ile karşıt anlamların bir arada oluşturulduğu bir kodaçımlama sürecidir. "İkinci konumumuz, müzakereli kod konumudur. [...] Müzakereli versiyon içindeki kodaçımlama, uyumlu ve karşıt unsurların bir karışımını içerir: Büyük anlamlandırmalar yapmak için egemen tanımların meşruluğunu kabul ederken, daha kısıtlı (sınırlanmış), durumsal 
(yerleşik) bir düzeyde, kendi kurallarını koyar, kuralın istisnalarıyla çalışır." (Hall, 2005: 97). Muhalif okuma ise, izleyicilerin medya metinlerini kodlayanların isteyip beklediklerinin tam aksi şekilde anlamlandırması, metinde hakim olan anlamlara karşı olmasıdır.

\begin{abstract}
"Son olarak, izleyicinin söylemi harfiyen ve yananlamsal olarak mükemmelen anlaması, ama mesajı global olarak (bütünüyle) aksi yönde kodaçımlaması mümkündür. Kişi mesajın bütüncüllüğünü bozarak, tercih ettiği kodla, alternatif bir referans çerçevesi içinde yeniden kurar. İzleyicinin ücretlerin kısılması üzerine bir tartı̧̧mayı dinlemesi, ama 'ulusal çıkarlar' sözünü her duyuşunda bunu 'sınıf çıkarı' olarak 'okuması' buna bir örnektir. Kişi karşıt kod olarak adlandıracağımız bir kod içinde hareket etmektedir." (Hall, 2005: 97)
\end{abstract}

Hukuki veya ahlaki suçlar ve cezaları işleyen TV dizilerindeki karakter ve öyküler üzerinden seyircilerin adalet anlayışlarının incelenmesi, izleyicinin medya metinlerini, onları üretenlerin niyetler, tercih ve beklentilerinden,veya metinlerin taşıdığı ideolojik bagajdan kısmen bağımsız bir tarzda okumalarının olası olduğunu belirten Hall'ün kavramsal çözümlemesi ile tutarlı bir çerçeve ortaya koymaktadır. Dizi seyircilerinin adalet anlayışlarındaki farklılaşmaların irdelenmesi adaletin göreliliğini, farklı okuma tarzlarının kabulü ise kodaçımlama (alımlama/okuma) biçimlerinin göreliliğine işaret eder.

$\mathrm{Bu}$ çalışma Hall'ün okuma biçimleri teorisinin doğrudan bir sınanması olmamakla birlikte, farklı okuma biçimlerinin mümkün olması fikri, çalışmanın merkezinde yer alan "adalet" kavramının göreliliği ile birlikte düşünülmüştür. Bu bağlamda dizi izleyicilerinin suç, ceza ve adalet hakkındaki yaklaşımlarının ve kabullerinin, konumlandıkları bağlamlara ${ }^{4}$ göre farklılaşacağı ve TV dizisinin anlatısı aracılığıyla adalet anlayışlarını irdelemeye yönelik sorulara da, bu anlatıları çeşitli biçimlerde okuyarak, farklı cevaplar verebilecekleri varsayılmıştır. Özetle, izleyici medya metinlerini farklı biçimlerde okuyabilen toplumsal bir eyleyen (fail/aktör), adalet kavramı ise göreli bir anlayış olarak kabul edilmiştir. $\mathrm{Bu}$ çalışmanın bulgular bölümünde veriler üzerine betimleyici açıklamalar ve izleyicilerin demografik nitelikleri ile bağlantılı olarak adaletin görelilik eksenleri bakımından değerlendirme ve çözümleme yapılırken, farklılaşan okuma tarzları üzerine Hall'ün geliştirdiği kavramsal çerçeveden yararlanılarak da analitik yorumlar yapılmıştır.

\title{
Adâlet Anlayışı ve Adâletin Göreliliği
}

İzleyicilerin dizilerdeki suç ve cezaya dair olayları nasıl bir adalet anlayışı ile ele alıp yorumladıklarını ortaya koymaya çalışmadan önce, adaletin ne olduğuna dair kuramsal açıklamalar yapmak gerekir. Adalet kavramını, hukuk teorileri içinden tartışmaya etraflıca girmek bu makalenin sınırlarını aşsa da adaletin göreli olduğu tezini açıklayıp tartışmak, verilerin analizi için elzemdir.

Adalet Kavramı adlı kitabında Anıl Çeçen "adalet" kavramıyla ilgili olarak, "hukuk ve felsefenin ana konularından biri" der ve çalışmasını "adaletin göreliliği" temeli üzerinde kurduğunu belirtir. (Çeçen, 1993: 7). Çeçen, adalet kavramının sözlüklerdeki düz anlamının yasalara uygunluk olduğunu ve genel olarak bu doğrultuda ele alınıp tanımlandığını söyler. Adaletin bu hakim kavranışııın, adaletin yasaları aşan boyutlarını göz ardı ettiğini vurgular. Devamında, adaletin "etik" ile ilişkisini ele alır ve adaletin hukuki taraflarına ek olarak, formel hukukun ötesinde, yani etik düzleminde incelenmesi gereken boyutları olduğunu söyler: "Adalet hem etik hem de hukuksal değer yargılarıyla içerik kazanır ve anlamı belirlenir." (Çeçen, 1993: 19) Anlaşılacağı üzere, aslında hukuksal adaletin görünümlerini değerlendiren kitabının daha başında adaletin hukuku aşan

\footnotetext{
${ }^{4}$ Bağlamın anlamlandırma sürecindeki rolü, antropoloji ve özellikle kültürlerarası iletişim çözümlemelerinde sıkça vurgulanır. Hatta kültürler, antropolog Edward T. Hall’ün (1959) yaptığı gibi iletișim kültürleri çerçevesinde yüksek ve alçak bağlamlı (low-high context) olarak sınıflandırılır. Ancak bu makalede, bağlam daha dar anlamda, izleyicilerin sosyoekonomik göstergeleri ve dünya görüşleri ile sınırlı kalınarak kullanılmıştır. Eleştirel kültürel incelemeler de bağlamın, metinlerin okunması ve anlamlandırmada önemini teslim eder. Alımlama çalışmalarında izleyicinin okuma bağlamını analizin merkezine alan özgün bir inceleme için bkz (Karabağ Sarı, 2013).
} 
boyutlarına, hem hukuk hem de etik disiplini içinde incelenebilecek unsurlarının merkezi meseleler olduğunu öne sürer. Ayrıca Çeçen'in "değer yargılarıyla" ifadesinde, çalışmasının temel savı da saklıdır: Adalet, evrensel bir hakikat değil, görelidir. Tüm değer yargıları gibi adalet anlayışı da mutlak değil değişkendir. Buna ek olarak çalışmasında Çeçen, adaletin görelilik ölçütlerini de tanımlar ve şöyle sıralar: "zaman, yer, sınıf ve dünya görüşü" (1993: 177-184).

Her ne kadar bu ölçütler, hukuksal adaletin ölçütleri ile örtüşse de, adalet sadece hukuki temelde konu edilmediği ve adaletin hukuk içi veya hukuk dışı boyutlarına ilişkin farklı düzeyleri barındığı için, bu izleyici araştırmasının bağlamına uygun olduğu düşünülmüştür. Bu çalışmada hukuki veya ahlaki suçlar ve cezalara dair geliştirilen sorular aracılığıyla TV dizisi izleyicilerinin adalet anlayışı soruşturulurken, üç temel eksen belirlenmiştir:

1) Formel hukuk içi bağlam ve yaklaşımlarla veya formel hukukun sınırlarını aşan yöntemlerle adaletin sağlanması, 2) Cezanın, bir tür kısas (denklik) anlayışıyla, suçluya acımasızca zarar verilmesi veya buna karşıt olarak suçluya mümkün mertebe az zarar vermek ve bu sayede onu ve onun aracılığıyla olası başka bireyleri suçtan mümkün oldukça uzak tutabilmek amacıyla verilmesi, 3) Suçun temelindeki güdüler ve nedenlerle buna bağlı olarak suçun sorumluluğunun da bireysel temelli veya yine buna karşıt olarak bireyi aşan yapısal-toplumsal temelli olduğu. Bu üç eksen etrafında tarama (sörvey) soruları, ikili karşıtlık içinde hangi anlayışın tercih edildiğini görebilecek şekilde tasarlanmıştır. Görgül bir araştırmada, araştırmanın en kritik noktası, kavram ya da kuramların, gözlenebilir dünyada karşılıklarını bulmayı sağlayacak olan işlemselleştirmedir (operasyonelleştirme). İzleyicilerin alımlama biçimleri ikili karşıtlık üzerinden tespit edilmeye çalış1ırken, adalet gibi yüksek bir soyutluğa tekabül eden bir olgunun, dizinin öyküsü ve karakterleri aracılı̆̆ıyla somut, gözlenebilir durumlara tekabül eden sorular aracığıyla ele alınabilmesine maksimum özen gösterilmiştir. Bu anlamda, izleyiciler tarafından anlaşılmayan, boş bırakılan ya da tutarsız bir şekilde cevaplanan bir soru olmaması, sormaca formunun operasyonel başarısı olarak kabul edilebilir.

\section{Suç ve Ceza Kavramlarını Düşünmek: Hukuk İçi-Hukuk Dışı Adalet İkilemi}

Metin Feyzioğlu, İlham Rahimov'un Suç ve Ceza kitabının Türkçe baskısına yazdığı Sunuş yazısında, suç ve ceza kavramlarının farklı tarihsel bağlamlarda, farklı anlam çerçeveleri içinden dönüşerek geliştiğini ve bu kavramların insanlık kadar uzun bir tarihe sahip olduğunu belirtir. Bununla birlikte kavramların birer hukuk kavramı niteliğine kısmen geç evrildiklerini fakat öncesinde felsefi ve dini yorumlamalarla tarih boyunca tartışılarak günümüze ulaştıklarını vurgular. Kitabın henüz başında Rahimov ceza olgusunun, hukuku aşan boyutlarına dikkat çeker: "Ceza ifadesi gerçek hayatta birçok anlamda; ahlâk, din, terbiye başta olmak üzere birçok alanda kullanılmaktadır" (2014: 9). Yaygın kabul gören manada ceza kavramı, kişinin gerçekleştirdiği bir cürümden nedeniyle gördüğü yaptırıma atfen kullanılır ve bahse konu eyleme karşılık olarak verilen cezanın faili, kimi eziyetlere maruz bıraktığı varsayılır. Hukuk alanında kavram, ceza hukukunun temelinde yer alan iki kavrama ayrılır: suç ve ceza. Rahimov, Rusçada, "ceza" anlamını içeren üç farklı kavramın olduğundan söz eder: Nakazaniye, kara, vozmezdiye. Bu kelimelerden birincisinin, gündelik yaşamda ve ceza hukukunda, dünyevi (seküler) ve dini referansla kapsamı geniş bir yaptırımlar alanına gönderme yapan bir kavram olduğunu; ikinci ve üçüncü kavramların ise daha fazla dini içerimle, suç karşısında verilen ilahi karşıllk anlamlarıyla kabul edildiğini belirtir. Suç ve ceza düşüncesinin gelişiminde çok önemli olduğu inkar edilemez F. Dostoyevski'nin Suç ve Ceza isimli ünlü romanında, en kapsamlı referansla kullanılan ilk kelimenin (Rusça nakazaniye) ve dini referanslı kullanılan üçüncü kelimenin (vozmezdiye) yer aldığını, ikincisinin ise (kara) hiç kullanılmadığını bildirir. Türkçede, "ceza" kelimesinin, bir ayrım gözetmeksiniz bu bağlamdaki tüm anlamları kapsadığını, hukukta gündeme geldiği gibi, sağ duyuya dayanan sosyal bilinçte de suçun karşılığ 1 olan yaptırım manasında aynı sözcügün tercih edildiğini ekler (Rahimov, 2014: 10). Rahimov, daha çok ceza hukuku üzerine bir tartş̧ma yürütse de, sorunun toplumsal, ekonomik ve kültürel 
veçhelerini ve toplumun profesyonel hukuk düzlemi dışındaki alanlarıla alakasını da gözardı edilemez bulur. Rahimov böylece, Anıl Çeçen'in "adalet" kavramı için söylediğine benzer şekilde, çalışmasının henüz başında "suç" ve "ceza"nın hukuki görünümleriyle birlikte, çok farklı kültürel boyutlarının var olduğunu ve bunların her türlü düşünsel tartışmada ciddiyetle ele alınması gerektiğini hatırlatır.

Alman felsefeci Karl Jaspers, Almanya'nın faşizm/nazizm meselesinde ulusal sorumluluğu üstlenmesi gerektiğini ileri sürdügü 1946 tarihli "Suçluluk Sorunu" adlı kitabında, sorunsalı analiz etmek için suç hakkında kavramsal bir tasnif oluşturur (2015). Jaspers'in tanımladığı suç türlerinden birincisi, "cezai suç"tur. "Nesnel olarak ispatlanabilir ve şüpheye yer bırakmayacak kadar açık yasaları ihlal eden eylemler" cezai suç sayılır. Bu suç türü için cezaya dair takdir yetkisi, mahkemelere aittir. İkinci kategori, "siyasi suç"tur. "Devlet adamlarının ve bir devlete vatandaşlık bağıyla bağlı herkesin eylemlerini kapsar." Bir ülkenin idare edilme şeklinin yani rejiminin, ülke vatandaşlarının ortak sorumluluğunda olduğuna dair bir kabule dayanır. Daha çok uluslararası bağlamda değerlendirilen bu suç türü, bir ulus devletin ve milletinin yaptıkları konusunda uluslararası sorumluluk taşıdığı, bu sorumluluğu tek tek tüm vatandaşların da üstlenmesi gerektiğine ilişkin bir sava yaslanır. Üçüncü suç türü, "ahlaki suç"tur. Bu suç kategorisi, "bireysel" bir suç türü olarak kabul edilmiştir. Birey olarak hareket eden kişinin, fiillerinden ahlaken sorumlu olduğuna ilişkin bir sav üzerine kuruludur. Örneğin siyasi ve askeri, farklı otoritelerin talimatlarını yerine getirse bile, insanın bireysel düzeyde ahlaki suç işlemiş olabileceği öne sürülür. Sorumlu bir otoritenin talimatı ya da emri de olsa, her fiil ahlaken sorumluluğa tabi kabul edilir. Bu suç kategorisinde hüküm mevki, kişinin kendi vicdanıdır. Dördüncü suç türü, "metafizik suç"tur. İnsanları, yeryüzündeki her adaletsizlik ve haksızlıktan, bilhassa tecrübesi, zamanı ve bilgisi dahilinde ortaya çıkan haksızlıklardan, tamamen sorumlu tutan bir anlayışa dayanır. Haksızlıklara mani olmak için elinden geleni yapmayan her bireyin, suçta pay sahibi olduğunu kabul eder. Başkalarının hayatı mevzu bahisken, onlanı korumak ya da gözetmek için inisiyatif almamanın, yaşamını tehlikeye atmaktan imtinâ etmenin, hukuksal, politik ve ahlaki açıdan anlaşılması güç bir suçluluk durumu ve duygusu ortaya çıkaracağını vurgular. Nihai olarak kendi hayatını tehlikeye atmak ya da risk almak yerine başkasının yaşamına etki eden haksızlıkları bir köşeden izlemenin de bir zorunluluk değil, bir tür seçim olduğu kabülü söz konusudur burada. Bu suç türünün cezalandırılmasıyla ilgili olarak yargılama yetkisi, sadece Tanrı'ya aittir. Jaspers'e göre, hukukun alanına ilk iki suç türü girer: Cezai suç ve siyasi suç. Ahlaki ve metafizik suç ise, formel hukukun alanına dahil değildir (Jaspers, 2015: 56-63). Anlaşılacağı üzere, ceza hukuku üzerine toplumsal koşulları ihmal etmeden düşünen Rahimov'un da kabul ettiği gibi, Almanya'nın politik sorumluluğunu ele alan Jaspers de suçun sadece hukukun alanında değerlendirilemeyecek boyutlarının olduğuna dikkat çeker.

Hilmi Ziya Ülken "Ahlâk" adlı çalışmasında (2016), ahlak felsefesini (etik) "kuramsal felsefe, sanat felsefesi ve pratik felsefe" diye üç temel kategori içinde ele alır. Bu üç kategoriyi de, genel felsefenin bir alt dalı olarak "pratik felsefe" başlığı altında sınıflandırır. Ülken, ahlak felsefesini çözümlerken, "yaptırımcılık" meselesine odaklanır. Bir bakıma, ahlaki meseleleri yaptırımcılık kavramı etrafında düşünerek, yukarıda sözedilen iki düşünürün suç olgusunun hukuki boyutları aşan yönlerinin olduğu fikrine katılmış olur. Ülken böylece konuyu, "etik" alanına dahil eder ve insan eyleminin, insanın kendi iradesine bağlı görünmesine rağmen, bütünüyle özgür, serbest ve bağımsız olarak yerine getirilmediğini söyler (Ülken, 2016: 273-279). Davranış tarzımızı saptarken, bu tercihlerin neticesinde ne tür muhtemel tepkilere maruz bırakılabileceğimizi hesap ettiğimizi, bunun da bir sınırlılık ortaya çıkardığını belirtir. Buradan yola çıkarak, Ülken'in çözümlemesi bağlamında davranışımızın "yanlış" olması durumunda maruz kalabileceğimiz tepkilerin "ceza", yanlış olduğu varsayılan davranışların da "suç" kapsamında ele alınabileceği ileri sürülebilir. Daha önce ele alınan düşünürler gibi Ülken de toplum içinde eylemde bulunmanın ve karşıllı̆ında çekilebilecek cezanın hukuksal tarafları kadar ve diğer toplumsal boyutlarını da vurgular. Toplumda insanın davranış 
özgürlüğünü sınırlandıran ve eylemini bütünüyle özgür iradesiyle gerçekleştirmesine müsaade etmeyen toplumsal yaptırımcılık tarzlarını, tabii, hukuki, dini, fikri ve ahlaki olarak tasnif eder. Ülken'in söz konusu kavramsallaştırması ve sınıflandırması, sosyal yaşamda suç ve cezanın farklı boyutlarıyla değerlendirilebileceğini gösterir. Ahlaki yaptırımcılığın ötekilere göre daha kapsamlı bir düzlemde hayata geçtiğini ve diğerleri kadar mühim olduğunun altını çizmesi, esasen etik alanında ele almayı gerektirecek denli ahlaki yönleri olduğuna işaret eder. Anlaşıldığı üzere Çeçen'in hukuksal ve hukuk dışı düzeyleriyle beraber göreli olduğunu belirttiği "adalet" nosyonunun içerimleri olan "suç" ve "ceza" olguları da, hem hukuki hem de hukuku aşan yönleriyle açıklanmaktadır.

Hukuk ve felsefe disiplinlerinden farklı düşünürlerin meseleyi kavramsallaştırma tarzlarına dayanarak, suç ve ceza konusu bu makalede hukuk içi ve hukuk dışı boyutlarıyla bir arada irdelenmiştir. "Dizi izleyicileri dizilerdeki olaylara ve karakterlere nasıl bir adalet anlayışıyla yaklaşmaktadır?" sorusunun cevabı aranırken, hukukun içinden değerlendirilebilecek adalet konusunun, esasen hukukun ötesinde, daha genel toplumsal problematiklere tekabül ettiği varsayılmaktadır. Hakim hukuk kanun ya da yasama teknikleri bakımından kurumsallaşmış ve hukuk pratiği formel bir işleyiş içindeki icraya tabi olsa da aslında hukuk, topluma dair bir dizi teorik kabule dayalıdır.

Bu kuramsal çerçeve "Dizi izleyicilerinin adaleti hukuk içi mi yoksa hukuk dışı mı kabul edip yorumladıkları" gibi bir araştırma sorusunu hem gerekçelendirir hem de gerekli kılar. Bununla birlikte bu soru, araştırmanın ve seyircilere yöneltilen soruların dayanağını oluşturan üç eksenden birini teşkil etmektedir ve izleyicilerin adaleti formel düzlemde hukuk içi mi, yoksa gayri hukuki yollarla mı sağlanmasını istedikleriyle alakalıdır. Adaletin hukuk dahilinde ve hukuk dışı boyutları ve anlamları olduğunu ve bunların hukuki adalete göre daha tali ve önemsiz sayılamayacağını gösteren yukarıda değinilen adalet teorilerinin tümü, bu eksenin bir dayanağıdır. Fakat Jaspers ve Ülken'in suç ve yaptırıma dair kavramsal çerçeveleri, sadece hukuk içi - hukuk dışı adalet sorgulamasına temel oluşturan teorik referanslar sayılmıştır.

\section{"Suç ve Ceza" Romanı Üstüne Düşünmek: Bireysel Suç - Toplumsal Suç Ayrımı}

Dostoyevski, ünlü romanında ilk olarak hukukla ilgili görünen "suç" ve "ceza" olgusunu, moral, ahlak ve vicdan ile ilişkilendirerek ve toplumsal mesuliyet meselesi birlikte, çok yönlü ve yoğun bir şekilde ontolojik ve psikolojik olarak sorgular. "Suç ve Ceza" romanını ele almak, farklı düşünürlerce çeşitli yönleriyle tasnif edilmiş olan "suç ve ceza"nın niteliğini tartışmak, bu makalenin temel sorusu açısından yararlı olacaktır. Gary Saul Morson'un "The Disease of Theory: Crime and Punishment at 150" (2016) başlıklı denemesinde ve Cemal Bâli Akal'ın "Hukuk Öğrencisi Raskolnikov Suç ve Ceza'yı Okumaya Mahkûm Edildi" isimli makalesinde dile getirdikleri gibi, Suç ve Ceza romanında Dostoyevski, suçun b irdelemiştir (Morson, 2016: 7) (Akal, 2014: 12). Hem Morson hem de Akal, Suç ve Ceza romanı etrafinda, muhtemel şartlar ve etkenlerin gerçekten suça neden olan unsurlar olup olmadığını, suçun özgür irade ve eğilime mi bağl1, yoksa toplumsal ya da ruhsal koşullarca belirlenen bir zorunluluk mu olduğunu sorgular.

Morson, Suç ve Ceza romanının kaleme alındığı tarihsel şartları hatırlatarak, Çar 2. Alexander'ın, tahta geçişinden başlayarak Rusya'da bir entelijansiyanın doğuşunu teşvik eden özgürlükçü ortam ve politikalarından bahseder. Bu hürriyet ikliminde ortaya çıkan entelektüellerin aykırı düşüncelerinin ve kuramlarının, bir dizi zararlı fiile sebep olduğunu, devrimci şiddetle buluştuğunu belirtir. Çar'ın, kendi geliştirdiği özgür toplumsal atmosfer içinde doğup büyüyen düşüncelerin sahiplerince öldürüldüğü tespitinde bulunur. Bunun ardından Suç ve Ceza üzerine detaylı bir çözümleme yapmaya başlar. Raskolnikov'un kendi eylemini ve tutumunu, bir suç değil, insanların iyiliği için elzem bir tercih veya yerine getirilmesi gereken bir misyon olarak gördügü hususları ele alır. Hayalci ve yaptığını meşrulaştırmaya çalışan bir çılgın görünümündeki Raskolnikov'un düpedüz bir suç işlediği sonucuna varır. Onu, gerçek hayata dokunmayan kuramlar, 
fikirler ve hayaller üzerinden düşünen ve eyleyen sağliksız bir birey sayar. Morson'a göre Dostoyevski de yarattığı karakter Raskolnikov'a hak vermekte, ahlaki anlayışını paylaşmaktadır. Roman kahramanın, öldürdüğü tefeci kadının suçsuz kardeşi Lizaveta'dan da kurtulmak için bir cinayet daha işlemeye mecbur kalmasını örnek göstererek, ne kadar gerekçelendirilmeye ya da haklı gösterilmeye çabalanırsa çabalansın, suçun hep masum insanlara acı verebileceğine dikkat çeker. İdeolojik hayalperestliğin somut davranışlara dönüştüğü anda ağır sonuçları olduğuna ilişkin saptamalar yapar. Morson meseleyi, soyut fikirlere gömülmüş Raskolnikov'un ütopik fikirleri üzerinden, entelektüel çevrelerce kuramlaştırılan ideolojik anlatıların bir patoloji ya da bir çeşit hastalık, hatta veba olduğuna bağlar. Kısmen (romanın sonundaki dini seçeneğe yönelmeyi takdir etmese de), suçun sorumluluğunun failde olduğunu, suçun şartlar ve bağlam tarafindan belirlenmiş ve zorunlu bir fiil olmadığını, ahlaki sorumluluğun ağır basması gerektiğini savunur (Morson, 2016).

Akal ise (2014), romanda öncelikle suçun işlendiği tüm sosyal, ekonomik kısaca dışsal şartları saptar ve Dostoyevski'nin mevcut şartlar altındaki duruşuna değinerek, suçu bunların hiçbirine bağlamadığını söyler. Akal, Dostoyevski'nin özgür iradeye bağlı ve böylece kişisel mesuliyeti belirleyici kılan suç anlayışına sahip olduğu fikrindedir. Raskolnikov'un bir tür delilik hâline yakın olduğunu da tespit eder, fakat yine benzer nedenlerle deliliğin de ahlaken sorumlu olmaktan muafiyet doğurmasından dolayı, Dostoyevski'nin suçun şartları olarak bunu da gözetmediğini ekler. Zira Dostoyevski'nin romanda, karakterlerini belli davranış ve fiilere yönelten şartları ayrıntılı ve layıkıyla serimlemediğini veya bunları kafi düzeyde anlatmadığını vurgular. Bunlarla birlikte Dostoyevski'nin yalnızca Raskolnikov'a dînî bir bakış kazandırarak, gelişmeleri ilahi bir adalet meselesine sürüklediğini, Sonya karakterinin fahişeliğe iten nedenleri ve koşulları hakkınca serimlediğini söyler. Böylelikle aslında diğer karakterleri için yapmamış olduğu "serbest seçim" savının geçersizleşmesine neden olduğunu belirtir. Yazara göre, Raskolnikov seçimini Tanrısal iradeye karşı yapmıştır. Yani Dostoyevski Raskolnikov için özgür bir seçim tesis etmiştir ve bu seçim ahlâki değildir. Yazar, Dostoyevski'nin bu cinayeti işletenin ne olduğu hakkında, maddeci ve nihilist bir akım ile Katolikler, Yahudiler, Müslümanlar, Almanlar ve Türkler gibi gücü hakla eşitleyenler fikrine ulaşır. Akal, direkt olarak belirtmese de, öteki karakterleri suça yönlendiren şartları tatmin edici düzeyde betimlemeyen ya da m Dostoyevski'nin Sonya mevzu bahis olunca, karakterini sahiplenmek için onu ahlaksız eylemlere yönelten şartları belirgin bir şekilde öne çıkardığını söyler (Akal, 2014).

Dizi seyircilerinin dizilerdeki olaylar, durumlar ve karakterlerle ilgili fikirlerine yaslanarak adalet anlayışının göreliliğini değerlendirmek adına yapılan bu çalışma için, Dostoyevski'nin Suç ve Ceza romanı üstünden geliştirilen argümanların, verilerin toplanması ve analizi açısından oldukça yararlı olduğu söylenebilir. Suç sorumluluğu konusuna dair bu iki farklı argüman, adaletin göreliliğini ortaya koyup tartş̧maya zemin hazırlar. Özellikle demografik değişkenler ve sosyoekonomik göstergeler (yaş, toplumsal cinsiyet, dünya görüşü, eğitim ve gelir durumu, medeni durum, iş/meslek) açısından suçun altında olan motivasyonların ve bununla ilişkili olarak suça dair mesuliyetin kişisel mi, yoksa toplumsal mı olduğu konusundaki yaklaşım farklı1ıklarının, adalet anlayışı üzerinde etkisi olup olmadığını irdelemeye imkan tanımıştır. Bu çerçevede "dizi izleyicilerinin suçun sorumluluğunun, suça temel oluşturan faktörlerin bireysel mi yoksa toplumsal $\mathrm{m} ı$ olduğuna dair düşüncelerinin ne olduğu" sorusu, izleyicilerin dizilerdeki olaylar ve karakterleri ne tür bir adalet anlayışı ile yorumladıkları genel problemi ışığında geliştirilen sorulardan ikincisi olmuştur. Bu da makalenin izleyicilerin adalet anlayışının göreliliğine ilişkin çözümlemesinin ikinci eksenini teşkil etmektedir.

\section{Cezanın Amacı: İntikam Almak - Suçtan Caydırmak İkilemi}

Antik Yunan'dan başlayarak, felsefede iyi ve kötü, doğru ve yanlış düşünce tarihi içinde sayısız tartışma ve incelemeye konu olmuştur. Suçun ve cezanın nitelikleri de bu düşünce tarihi içinde ele alınmıştır. Fakat çağdaş ceza hukukunun temeli, modernite ve onun içindeki reformasyon 
ve hümanizm hareketleri ile oluşturulmuştur. Montesquieu'nun Yasaların Ruhu (1748) adlı kitabından yoğun bir şekilde etkilenen ve çağdaş ceza hukukunun kurucu düşünürü kabul edilen Cesare Beccaria da 1764 yılında Suçlar ve Cezalar Hakkında isimli çalışmasını yayınlar. Beccaria (2018: 69-70), suç ve ceza olgusunu "toplum sözleşmesi" fikri üzerine kurar. Bir toplumdaki her bireyin sahip olduğu özgürlüklerinin mümkün en küçük bölümünden, diğer insanları kendilerini korumakla yükümlü k1lmak adına, vazgeçtiklerine (feragat) inanır. Bu "küçük özgürlük parçacıklarının" toplamı, bir toplumun bireyleri cezalandırma hakkına sahip olmasını sağlar. Beccaria, "cezanın amacinın, sadece, suçlunun yeniden topluma zarar vermesine engel olmak ve başkalarını aynı şeyi yapmaktan alıkoymaya (caydırmak) kayıtlı olduğunu" savunur. Cezanın, olabildiğince kişiyi suçtan uzak tutacak şekilde fakat bireyin fiziki varlığına, bedenine olası en az zararla uygulanmasını gereğine işaret eder (Rahimov, 2014: 30). Bu argümandan yola çıkarak, bu araştırmada dizi seyircilerinin ceza uygulamalarında acımasızlığa dair tutum ve yaklaşımları öğrenilmeye çalışılmıştır. Beccaria'nın üzerinde durduğu aslında hukuki anlamda suç ve ceza ile sınırldır. Fakat bu araştırma bağlamında, hukuk içi ve hukuk dışı olması belirleyici kabul edilmeksizin, cezalar hakkında seyircilerin, "topluma mümkün olan en fazla fayda ve suçluya mümkün olan en az zarar mı, yoksa suçluya intikamcı bir acımasızlıkla zarar verme taraftarı mı?" olduklarına ilişkin bir soru daha formüle edilmiştir. Bu soru ise araştırmanın üçüncü eksenini kurmuştur. $\mathrm{Bu}$ sayede adaletin göreliliğine ilişkin soruşturmanın bir yönü de bu husustaki yaklaşımlar olmuştur.

Özetle dizi izleyicilerinin adalet anlayışlarının göreliliğine, diğer bir deyişle bu anlayışların nasıl değiştiği ve farklılaştığına ilişkin üç ana eksen şunlardır: a) adaletin hukuk içi mi, yoksa hukuk dışı mı sağlanması gerektiği, b) suçun temelinde yatan güdü ile suçun sorumluluğunun kişisel mi yoksa toplumsal mı olduğu ve c) cezaların öç almacı bir motivasyonla mı, yoksa suçlu için en az zarar ve toplum için en yüksek fayda anlayışıyla mı verilmesi gerektiğine ilişkin sorgulama eksenleri olmuştur.

\section{Çukur Dizisinin Öykü ve Karakterleri}

Çukur dizisinin ${ }^{5}$ hikayesi, "Koçova Mahallesi" adında bir mahallede geçer. Çukur, mahalle halkının oraya kendilerince verdikleri addır. Bu mahalle, uzun zaman önce, gençken oraya gelmiş ve mahallenin koruyup, kollayanı yani bir tür "babası (hamisi)" olmuş İdris Koçovalı ve onun ailesi tarafından idare edilen, uyuşturucuya kesinlikle müsaade edilmeyen ancak onun haricinde her türden illegal işin görüldüğü bir mahalledir. Çukur'un "babası" İdris Koçovalı ve ailesinin silah kaçakçılığı ve tüccarlığı bile yapılan, kanun dışı işlerin yürütüldüğü bir mekândır. Çukur'a yabancılar hatta polis dahi giremez, zaten geleceği zaman da önceden bilgi verilir. Çukur, kendi kurallarına sahiptir ve kendi adaletini bizzat kendi tesis eder. Hatta dizinin ilk bölümlerinde, bu kendi kurallarına (hukukuna) sahip olma hali çok çarpıcı bir şekilde izleyiciye gösterilir. Koçovalı ailesinin büyük oğlu Kahraman Koçovalı, bir çocuğu istismar etmiş bir adamı kafasını taşla parçalayarak öldürür. Koçovalı ailesi Çukur'da cezayı kendisi belirlemiş ve infazı da yerine getirmiştir. Bir gün Çukur'a Vartolu Saadettin adında biri gelir ve mahallede uyuşturucu üretip satmak ister. İdris bunu kabul etmez ve karşı çıkar. Buna karşı Vartolu, İdris'in büyük oğlu ve daha önce çocuk istismarcısini feci şekilde öldüren Kahraman'ı öldürür. Bunun üstüne Koçovalılar da onun adamlarını öldürürler, düşmanlık ve çatışma büyür ve ilerler. Hikayenin ilerleyen bölümlerinde Vartolu Saadettin'in, İdris'in gençliğinde ilişki yaşadığı bir hayat kadınından doğan oğlu Salih olduğu açığa çıkar. İdris'ten

\footnotetext{
${ }^{5}$ Çukur Tv dizisi, Ay Yapım şirketi tarafından çekilmiştir ve Show TV kanalında 23 Ekim 2017 tarihinde yayınlanmaya başlamıştır. Yıllık ortalama 30 bölüm ile 93. bölüme ulaşmıştır. Gösterimi devam eden aksiyon ve dram türündeki dizinin yönetmeni Sinan Öztürk, senarist Gökhan Horzum ve Damla Serim'dir. Gökhan Horzum, 2019 yılının Ekim ayında "Yamaç'ın Dönüşü - Çukur" adında dizinin ilk sezonunu anlatan bir kitap çıkarmıştır. Birçok üniversiteden, öğrenci anketlerinin sonuçlarına göre ödül alan dizi, gösterildiği 3 sezon boyunca reyting sıralamalarında genel olarak günün en çok izlenen ilk üç dizisi içinde yer almaktadır. Dizi aynı zamanda 2019 yılı 6. TÜRKIYYE ALTIN PALMIYE ÖDÜLLERİ'nde yılın aksiyon dizisi seçilmiştir (https://www.ayyapim.com/tr-tr/odullerimiz erişim 01.06.2020).
} 
habersiz bir şekilde (hapistedir o dönem), dünyaya gelen ve İdris'in eşinin talebiyle mahalleden başka biriyle evlendirilen Mihriban'ın çocuğu Salih'tir bu yeni düşman. Mihriban zoraki evlendirildiği adam tarafından öldürülmüş, Salih de daha bebekken doğuda bir yakınının yanına verilmiştir. Salih, kendisini sahiplenecek birisi olmadığından, çocukluğunu kötü şartlarda geçirmiş ve suça karışmıştır. Yetişkin olduğunda, İdris'ten intikamını almak üzere doğduğu mahallesine, Çukur'a geri gelmiştir. Bu arada İdris'in küçük oğlu Yamaç Çukur'da aile liderliğini üstlenmiştir. Yamaç'ın büyüğü Selim Koçovalı ise, çocukluğundan itibaren ailesi tarafından ikinci plana itildiği düşüncesiyle, ihanete yönelir ve Vartolu ile ailenin başka düşmanlarıyla işbirliğine girer. Şu halde suçla dolu bir hayat sürdüren Koçovalı ailesi ve mahalleli, diğer suçlu ve dizinin "kötü”sü görünümündeki Saadettin'le süren ve giderek keskinleşen bir düşmanlığın içine girmiş olur.

\section{Yöntem ve Teknik}

Dizinin seyircilerine yönelik olarak yapılan bu inceleme, önceki başlıklarda değinilen üç temel soru ve bunlarla ilişkili olarak tanımlanan üç ana eksen etrafında dizi anlatısıyla alakalı geliştirilen soruların seyircilere yöneltilmesiyle verilerini oluşturmuş, Aysel Aziz'in "yaygın gözlem yöntemi" diye tanımladığı türden nicel bir tarama araştırmasıdır (2017: 82-83). Keith Punch'ın (2003: 1-4) tarifine göre "küçük ölçekli niceliksel tarama çalışması" sayılabilir. Araştırma, olabildiğince fazla sayıda dizi izleyicisine ulaşarak, verilen cevapların belirlenen değişkenler temelinde oransal dağılımları gözlenerek, bu değişkenler etrafında oransal farklılaşmaların ortaya koyulmasına, bu sayede adaletin ayrı değişkenler bakımından görünümlerini tepsit etmek için dizayn edilmiştir.

Anket soruları, iki ana soru seti altında formüle edilmiştir. Birinci soru kümesi, seyircilerin demografik niteliklerine ilişkin veriyi toplamak için oluşturulmuştur ve yaş, toplumsal cinsiyet; medeni, eğitim, meslek ve gelir durumu ve dünya görüşünü öğrenmeye yöneliktir. İkinci soru seti ise dizinin anlatısına (öykü ve karakterler) dair yukarda açıklanan ve araştırmanın temel sorusuna cevap üretmeyi sağlayacak olan üç eksende hazırlanmış sorulardır. Bu sorular, demografik ve sosyoekonomik durumu betimleyen verilerle ilişkileri bağlamında, Anıl Çeçen'in adaletin görelilik ölçütleri başlığında sıraladığı "zaman, yer, sınıf, görüş" kategorilerinden de hareketle değerlendirmek üzere oluşturulmuştur.

Dizinin seyircilerine ulaşabildiğimiz oranda hiçbir ölçüte göre sınırlamaya gitmeden anketler uygulanmıştır. Ayrıca, internet üzerinden hazırladığımız soru formunu dizinin en çok takip edilen sosyal medya hesaplarının ve platformlarının yöneticilerine göndererek, onların gruplarında paylaşmaları ve sosyal medya takipçilerinden anketi cevaplayanların da ulaşabildikleri diğer izleyicilere veya sosyal medya hesaplarına formun ağ bağlantısını iletmelerini istedik. Bu örneklem çıkarma şekli, Aysel Aziz'in "Kartopu Örnekleme" olarak tanımladığı örneklem tekniğine ve basit rastlantısal örnekleme olarak isimlendirilen metoda uyan bir stratejidir (Aziz, 2017: 52-56). Bu örneklem çıkarma yönteminin, evreni yani bu dizinin bütün izleyicilerini temsiline hizmet edip etmediğini gösterecek bir ölçütümüz olmamakla birlikte, ulaşılan toplam 200 izleyiciden fazla katılım sayısının kayda değer olduğu ileri sürülebilir. Bununla birlikte, araştırmada resmedilmesi düşünülen konu adaletin göreliliği olduğundan, göreliliğin betimlenebilmesi de mutlak genellemeye ulaşmayı gerektirmediğinden örneklemin evreni temsil kabiliyetinin yaşamsal olmadığı söylenebilir. $\mathrm{Bu}$ anlamda nicel araştırmalar için önemli iki kriter olan güvenilirlik ve geçerliliğin, bu araştırma için örneklemin temsil gücü ile değil, adalet gibi kavramsal bir sorunun empirik olarak gözlenebilir göstergelerini oluşturan anket sorularının verimli bir şekilde formüle edilebilmesiyle sağlandığı vurgulanmalıdır. Adalet anlayışının göreli olduğuna ilişkin varsayımın tartışılıp değerlendirilebilmesi için örnek büyüklüğünün ve anket ile toplanan verinin nicelik ve niteğinin yeterli olduğu söylenebilir.

$\mathrm{Bu}$ çerçevede hazırlanmış sorulara verilen cevaplar, a) adaletin resmi hukuk içinde veya formel hukukun dışında sayılabilecek yollarla sağlanması, b) cezanın amacının suçluya ruhen ve fiziken zarar vererek intikam almak veya suçluya az zarar vererek suçtan suçtan uzaklaştırıp terbiye 
etmeye çalışmak olması ve c) suçların altındaki sebepler bağlamında sorumluluğun bireysel ya da toplumsal-dışsal olması biçiminde formülleştirilen üç araştırma ekseninde analiz edilmiştir. Adaletin göreliliği, seyircinin medya karşısındaki konumu aracılı̆̆ıyla yani medya ile seyircilerin buluştuğu bir düzlemde değerlendirildiği için, tüm bu veri kümesindeki anlamlı ayrımlar açıklanıp çözümlenirken Hall'ün kavramsallaştırdığı okuma biçimleri/ okur konumlanmaları bağlamında yorumlamalar da gidilmiştir.

\section{İzleyici Profili, Demografik Dağılım ve Sosyoekonomik Durum}

Dizi anlatısıyla (öykü ve karakter) alakalı soruların değerlendirme kriteri olarak belirlenen sosyoekonomik gösterge ve demografi verilerini toplamak için geliştirilen yedi soruya ait, Çukur dizisi anketine katılanların verdikleri cevapların dağılımı aşağıdaki tablolarda görülmektedir.

Tablo 1: İzleyici Cinsiyet Dağılımı

\begin{tabular}{lr|r|r|r} 
& Siklık & \multicolumn{1}{c}{$\%$} & Geçerli $\%$ & \multicolumn{1}{c}{ Toplam \% } \\
\hline Erkek & 102 & 49,3 & 49,3 & 49,3 \\
\hline Kadın & 105 & 50,7 & 50,7 & 100,0 \\
\hline Toplam & 207 & 100,0 & 100,0 & \\
\hline
\end{tabular}

Araştırma anketine katılan toplam 207 izleyiciden 102 kişi erkek, 105'i kadındır. Böylece erkekler, toplam katılımcı oranının \% 49,3'ü kadınlarsa \% 50,7'si olarak, yarı yarıya bir dağılım göstermiştir.

Tablo 2: İzleyici Yaş Dağılımı

\begin{tabular}{l|r|r|r} 
& Sikl1k & Oran $\%$ & Toplam \% \\
\hline 18 'den küçük & 10 & 5 & 5 \\
\hline $18-25$ aras1 & 71 & 34 & 39 \\
\hline $25-35$ aras1 & 101 & 49 & 88 \\
\hline $35-45$ aras1 & 16 & 8 & 96 \\
\hline $45-55$ aras1 & 8 & 4 & 99 \\
\hline $55-65$ aras1 & 1 & 0,5 & 100,0 \\
\hline Toplam & 207 & 100,0 & \\
\hline
\end{tabular}

Yaş tablosunda da görüldüğü üzere, toplam katılımcı sayısının \%49’u 25-35 yaş arası izleyicilerdir. 18-25 yaş aralığındaki seyirciler toplamın \% 34'nü oluşturmaktadır. Yaklaşık \% 5 oranında izleyici 18 yaşından küçüktür. \%8 oranında 35-45 yaş aralığında, \%4 45-55 yaş arası seyirci vardır. 55-65 yaş aralığında ise sadece 1 izleyici ankete katılmıştır.

Tablo 3: İzleyici Medeni Hâl Dağılımı

\begin{tabular}{lr|r|r|r} 
& Siklık & $\%$ & Toplam \% \\
\hline Evli & 61 & 30 & 29,5 \\
\hline Bekâr & 138 & 67 & 96,1 \\
\hline Boşanmış/Dul & 8 & 3 & 100,0 \\
\hline Toplam & 207 & 100,0 & \\
\hline
\end{tabular}

Çukur dizisi izleyicilerinden katılımcıların \%30'u evli, \%67'si bekâr, \%4'ü de boşanmış/dul seçeneğini işaretlemiştir.

Tablo 4: İzleyicilerin Eğitim Durumları Dağılımı

\begin{tabular}{lr|r|r|r|r} 
& \multicolumn{1}{c}{ Sıklı } & $\%$ & Geçerli \% & Toplam \% \\
\hline Düşük eğitimli & 16 & 8 & 8 & 8 \\
\hline Orta eğitimli & 37 & 18 & 18 & 26 \\
\hline Yüksek eğitimli & 154 & 74 & 74 & 100,0 \\
\hline
\end{tabular}




\begin{tabular}{|c|c|c|c|c|}
\hline Toplam & 207 & 100,0 & 100,0 & \\
\hline \multicolumn{5}{|c|}{$\begin{array}{l}\text { Eğitim durumu açısından dağılıma bakıldığında, örneklem dahilindeki izleyicilerin } \\
\text { çoğunluğunun yüksek öğrenim mezunu olduğu görülmektedir. Yüksek eğitimliler \% } 74 \text { oranında, } \\
\text { orta eğitimliler yaklaşık \% } 18 \text { oranında, düşük eğitimliler ise } \% 8 \text { oranında olmuştur. }\end{array}$} \\
\hline \multicolumn{5}{|c|}{ Tablo 5: İzleyici Meslek Dağılımı } \\
\hline & Siklık & $\%$ & Geçerli \% & Toplam \% \\
\hline Esnaf & 8 & 4 & 4 & 4 \\
\hline Sanatçı & 6 & 3 & 3 & 7 \\
\hline Ev Hanımı & 15 & 7 & 7 & 14 \\
\hline İşçi & 20 & 10 & 10 & 24 \\
\hline Öğrenci & 58 & 28 & 28 & 52 \\
\hline Memur & 30 & 14 & 14 & 66 \\
\hline Emekli & 1 & 0,5 & 0,5 & 67 \\
\hline İşsiz & 21 & 10 & 10 & 77 \\
\hline Diğer & 48 & 23 & 23 & 100,0 \\
\hline Toplam & 207 & 100,0 & 100,0 & \\
\hline
\end{tabular}

Çukur dizisi izleyici anketi katılımcılarının sırasıyla yaklaşık \%4'ü esnaf, \%3'ü sanatçı, \%7'si ev kadını, \%10'u işçi, \% 28'i öğrenci, \% 14''u memur, \% 0,5'i emekli, \%10'u işsiz, \%23'ü ise diğer şıkkını işaretlemiştir. Diğer şıkkını yönelenlerin yazdıkları meslek isimlerine bakıldığında öğretmen, hekim, kameraman, biyolog, farklı kelimelerle not edilmişse de gene öğrenci, akademisyen, muhasebeci vb cevapların yazıldığı görülmüştür. Yazılanlar arasında sınıfsal olarak oluşturulmuş seçeneklerden ayrı bir uğraşı belirten bir meslek ismi yazılmamıştır. Yazılan meslek isimleri mevcut seçenekler listesine uzak değildir. Bu yüzden anket formunda ya da istatistiki betimlemede ayrı meslek grubu başlı̆̆ belirleyi gerektiren bir sonuç söz konusu değildir.

Tablo 6: İzleyicilerin Gelir (Ekonomik) Durumu Dağılımı

\begin{tabular}{lr|r|r|r} 
& Siklık & $\%$ & Geçerli $\%$ & Toplam \% \\
\hline Çok düşük gelirli & 35 & 17 & 17 & 17 \\
\hline Düşük gelirli & 140 & 68 & 68 & 85 \\
\hline Normal sınır ve üstü & 32 & 15 & 15 & 100,0 \\
\hline Toplam & 207 & 100,0 & 100,0 & \\
\hline
\end{tabular}

Anketine katılan toplam 207 izleyiciden 35'i çok düşük gelirli, 140'1 düşük gelirli, 32'si ise normal sınır ve üzerinde gelire sahip olduklarını beyan etmiştir. Çok düşük gelirliler toplamın $\% 17$ 'sine, geliri düşük olanlar toplamın \% 68'sine, normal ve üstünde gelire sahip olduğunu belirtenlerse toplamın \%15'ine denk gelmektedir.

Tablo 7: İzleyicilerin Dünya Görüşü Dağılımı

\begin{tabular}{lr|r|r|r|} 
& Siklık & \multicolumn{1}{c}{$\%$} & Geçerli $\%$ & Toplam \% \\
\hline Să̆ görüşlüler & 88 & 42 & 42 & 42 \\
\hline Sol görüşlüler & 99 & 48 & 48 & 90 \\
\hline Diğer & 20 & 10 & 10 & 100,0 \\
\hline Toplam & 207 & 100,0 & 100,0 & \\
\hline
\end{tabular}

Dünya görüşüne göre izleyici dağılımda, toplumsal cinsiyet değişkenindeki dağılıma benzer şekilde, diğer göstergelere göre biraz daha homojen bir tablonun sözkonusu olduğu söylenebilir. 88 kişi olan sağ görüşlüler toplam katılımcı sayısının \%42'si, 99 kişi olan sol görüşlüler toplam katılımcıların \%48'idir. "Diğer" şıkkını yönelen 20 izleyici ise, toplam sayının yaklaşık \%10'nu oluşturmaktadır. 
Demografik veri toplamaya yönelik toplam 7 sorudan sadece cinsiyet ve dünya görüşü sorularında katılımcı izleyicilerin sunulan şıklara göre dağılımı benzer oranlarda yani homojen denebilecek bir dağılımda olmuştur. Diğer değişkenlerde eşit dağılım denebilecek bir görünüm söz konusu olmamıştır. Araştırmanın kendi kısıtları dahilinde türdeş dağılım göstermemiş olan değişkenlere bakımından yapılacak değerlendirmenin, ötekilere kıyasla daha zayıf olacağı düşünülebilirse de bütün değişkenlere göre erişilebilmiş katılımcı seyircilerin verdikleri cevaplar değerlendirilmiştir. Bununla birlikte genel olarak, istatistiki anlamda normal dağglım ya da toplumun -bu araştırma bağlamında izler kitlenin- sosyoekonomik değişkenler bakımından homojen bir dağılıma sahip olduğu teorik bir varsayımdan ibarettir.

Çukur dizisi anketine katılan izleyicilerin demografik ve sosyoekonomik profilini özetlersek, yaklaşık yarı yarıya erkek ve kadın katılımcı olmuştur. \%80'in üzerinde 18-35 yaş aralığındaki gençlerden oluşan, çoğunluğu bekâr, \%75'e yakın oranda yüksek eğitimli, öğrenci ve memur sayısı göreli olarak yüksek, çoğunluğu düşük gelirli (yaygın ekonomik göstergelere göre açlık sınırı üstünde, yoksulluk sınırının altında gelire sahip) ve yakın (eşit) oranda sol ve sağ görüşlülerden oluşan bir Çukur seyirci grubuna ulaştığımız ifade edilebilir. İzleyicilerin suç ve ceza, hukuki ve gayri hukuki gibi ikilikler etrafında adalet anlayışlarını ortaya koymaya çalışırken, üzerine yorum yapılan seyirci sosyal profilinin, izleyicilik meselesini tartışmak açısından yeterli bir çeşitliliğe sahip olduğunu söyleyebiliriz.

\section{İzleyici ve Adalet Kavrayışları: Dizinin "Düşman" Kahramanı ve Hukuk}

Tablo 88: Çukur'da Kahraman Kimdir Hakkındaki Yanıtların Dă̆ılım

\begin{tabular}{lr|r|r|r|r} 
& Siklık & $\%$ & Geçerli \% & Toplam \% \\
\hline İdris Baba & 19 & 9 & 9 & 9 \\
\hline Yamaç (Oğul) Koçovalı & 93 & 45 & 45 & 54 \\
\hline Vartolu Saadettin & 67 & 32 & 32 & 87 \\
\hline Diğer & 28 & 13 & 13 & 100,0 \\
\hline Toplam & 207 & 100,0 & 100,0 & \\
\hline
\end{tabular}

Dizinin kahramanının kim olduğuna ilişkin soruya verilen cevapların \%9'u İdris Baba'yı, yaklaşık \% 45'i Yamaç Koçovalı'y1, \% 32,4'ü Vartolu Saadettin'i, \% 13'ü diğer karakterleri belirtmektedir. Diğer şıkkını seçenler içinde, dizinin yardımcı karakterlerinden bazılarının ismini yazanlar da olmuştur. Yamaç Koçovalı ve Vartolu Saadettin'i dizinin kahramanı olarak kabul etme ya da görme oranlarının yüksek olduğu açıktır. Dizinin kahramanı olarak mevcut seçenekler arasında bir kadın seçenek olmamıştır çünkü öne çıkan bir kadın karakter yoktur. Fakat, diğer şıkkına yönelerek öteki karakterlerin de kahraman olarak belirtilmesi mümkünken, diğer şıkkının seçilme oranı da zaten düşük kalmış, işaretleyenlerden herhangi bir izleyici de kadın karakterlerden birini belirtmemiştir. Diğer başlığı ile yine yan veya yardımcı erkek karakterler yazılmıştır. Çukur'un anlatısı içinde her ne kadar mücadele eden, çatışan tarafların hepsi yasal olarak suç sayılabilecek işler içinde olsalar da, dizi anlatısında doğru/meşru taraf biçiminde sunulan, daha doğrusu anlatıda yapımcılarca iyi/kahraman olarak kodlanan Koçovalı ailesidir. Bununla birlikte Koçovalı ailesinin üyesi olan karakterler kadar yüksek olmasa da \%30'un üzerinde"düşman" karakter Vartolu'nun kahraman olarak işaretlenmiş olması da dikkate değerdir. Bu bakımdan, \%30'un üzerinde katılımcı seyircinin, dizinin kahramanı konusunda karşıt okuma yaptıkları söylenebilir. Önemli oranda seyircinin, dizi anlatısının düz anlam düzeyinde düşman ya da "kötü" karakterini kahraman olarak görmesi, suç-adalet, hak-meşruiyet bağlamında adalet anlayışının göreliliğini vurgulayan bir bulgu olarak yorumlanabilir.

Kadın ve erkeklerin hangi şıkları yönelip, kimleri kahraman olarak gördüklerine bakıldığında, her iki cinsiyet için de \%45 oranlarında Yamaç, \%30'un üzerinde de Vartolu seçeneğinin tercih edildiği görülmüştür. Kadınların belli bir seçeneğe, erkeklerin ise diğer seçeneğine yoğunlaşmaları, yani cinsiyete göre belli yanıtlarda yığılma görülmemiştir. Fakat dünya görüşü 
gündeme getirilse, Yamaç'ı kahraman görme oranı sağ görüşlülerde $\% 51$, sol görüşlülerde ise $\%$ 46,5; Vartolu'yu kahraman sayma oranı ise sağ görüşlülerde $\% 28$, sol görüşlülerde ise $\% 34$ 'tür. Aradaki farkın yüksek olduğu söylenemese de, sol görüşlülerin sağ görüşlülere oranla daha düşük düzeyde Yamaç'ı, daha yüksek Vartolu'ya kahraman olarak yorumladıkları görülmektedir. Dizinin yeğlenen, hakim kodlaması Koçovalı ailesinin haklı/meşru olduğu yönündedir. Bu kodlamaya karşı, Koçova ailesi mensuplarının değil de, onların yüzünden zorlukla hayatta kalmış düşman karakter olarak sunulan Vartolu'nun kahraman (meşru) görülmesi, sol görüşlülerde daha yüksek olmuştur. Sol görüşlülerde gözlenen bu okuma biçimini, onların toplumda hakim olan hukuk, adalet ve ahlaki değerlere (suç-ceza) yönelik, hafif düzeyli (oranlar belirgin bir ayrıksılık göstermediğinden) bir muhalefetin işareti olarak yorumlamak yanlış olmaz.

\section{Çukur İzleyicisi ve Hukuk İçi Adalet Sorunu}

Çukur dizisi izleyicisine, adaletin resmi hukuk içi (formel) mi yoksa hukukun dişında (enformel) mı sağlanmasını daha çok tercih edecekleri konusunda yöneltilen sorulara verilen cevapların genel dağılımı, aşağıdaki tablolarda gösterilmektedir.

\begin{tabular}{|l|r|rc|rr}
\multicolumn{5}{c}{ Tablo 9: Koçova Mahallesi Hakkındaki Tanımların Dağllımı } \\
& Siklık & \% & Geçerli \% & Toplam \% \\
\hline Bir suç mahallesidir. & 138 & 67 & 67 & 67 \\
\hline Adaletli bir mahalledir. & 52 & 25 & 25 & 92 \\
\hline Diğer & 17 & 8 & 8 & 100,0 \\
\hline Toplam & 207 & 100,0 & 100,0 & \\
\hline
\end{tabular}

"Polisin dahi giremediği, bir çok suçun işlendiği fakat uyuşturucuya müsaade edilmeyen Koçova Mahallesi hakkında ne düşünürsünüz?" şeklindeki bu soruda ilk şık, adaletin hukuk içi kavrandığına, ikincisiyse adaletin hukuk dışı kavrandığına yorulmak üzere hazırlandı. İzleyici katılımcıların yaklaşık \% 68'i Çukur'un bir suç mahallesi olduğu yönündeki birinci şıkkı, \% 25'i adaletli bir mahalle olduğuna ilişkin şıkkı, \%8'i ise diğer seçeneğini işaretlemişlerdir. Görüldüğü üzere, seçeneklerden birincisi çok daha fazla tercih edilmiştir.

Tablo 10: Çocuk İstismarcısı Hakkındaki Düşüncelerin Dağılım

\begin{tabular}{|l|r|r|r|r} 
& Sıklık & $\%$ & Geçerli \% & Toplam \% \\
\hline Haklıdır, cezasını vermiştir. & 69 & 33 & 33 & 33 \\
\hline Onun yaptığı da suçtur, cezayı mahkemeler vermelidir. & 134 & 65 & 65 & 98 \\
\hline Sapıklık cezasını Allah'tan bulmalıydı. & 4 & 2 & 2 & 100,0 \\
\hline Toplam & 207 & 100,0 & 100,0 & \\
\hline
\end{tabular}

"Kahraman Koçovalı'nın, çocuk istirmarcısının başını taşla ezmesi konusunda ne düşünüyorsunuz?" sorusunda, birinci seçenek bunun hukuk dışı (enformel) bir adalet sağlama eylemi olduğunu, ikinci şık hukuki bir adalet anlayışı olduğunu, üçüncüsü ise yine hukuk dışı ve/veya dinsel bir adalet anlayışı olduğuna tekabül etmesi öngörülerek hazırlandı. Katılımcı izleyicilren \%33'ü "Haklıdır, cezasını vermiştir." seçeneğini, yaklaşık \% 66'sı "Onun yaptığı da suçtur, cezayı mahkemeler vermelidir/vermeliydi." ifadesini, \%2'si ise "Sapıklık cezasını Allah'tan bulmalıdır" şıkkını işaretlemiştir. Bu üçüncü şık, ayrıca hukuk dışı adaletin, Jaspers'in metafizik suç ve Ülken'in dini yaptırımcılık kavramları çerçevesinde düşünülerek bir tür dinsel adalet kavrayışına yorumlanabilecek bir söylem olarak hazırlanmıştı. Fakat görüldüğü gibi seçilme oranı çok düşük seviyede kalmıştır. Bu yüzden, hukuk dışı adaletin dini formu üstüne ayrıca bir değerlendirmeye lüzum görülmemiştir. Buradan yola çıkarak izleycilerin suç-ceza ilişkisinin hukuki boyutlarını dolayısıyla adaletin yerine gelmesi ile ilgili anlayışlarının dini referanslara sahip olmadığını, meselenin genel olarak dünyevi bir çerçeve içinde değerlendirdiğini söyleyebiliriz. 
Tablo 11: Vartolu'nun Mahalleye Yaptıklarının Haklılığı/Meşruiyeti Hakkındaki Dağılım

\begin{tabular}{|c|c|c|c|c|}
\hline & S1klık & $\%$ & Geçerli \% & Toplam \% \\
\hline $\begin{array}{l}\text { Vartolu haklıdır, annesini kaybetmesinin ve } \\
\text { yaşadıklarının karşılığını vermektedir. }\end{array}$ & 35 & 17 & 17 & 17 \\
\hline $\begin{array}{l}\text { Vartolu haksızdır, Çukur'un düzenini } \\
\text { bozmamalı, Çukur ailesine zarar vermemelidir. }\end{array}$ & 45 & 22 & 22 & 39 \\
\hline $\begin{array}{l}\text { Çukur'daki herkes gibi o da suçludur, hepsi ile } \\
\text { birlikte cezalandırılmalıdır. }\end{array}$ & 127 & 61 & 61 & 100,0 \\
\hline Toplam & 207 & 100,0 & 100,0 & \\
\hline
\end{tabular}

"Vartolu'nun, uyuşturucu işini engellediği için Kahraman Koçovalı'yı öldürmesi ve Çukur'la mücadele etmesi konusunda ne düşünüyorsunuz?" şeklinde hazırlanan bu soru, ilk iki seçeneği hukuk dışı adalete, üçüncü şık ise hukuki adalete inanmanın göstergesi olarak hazırlandı. Katılımcıların yaklaşık \%17'si birinci şıkk1, \%22'si ikinci şıkk1, \%61'i ise üçüncü şıkkı işaretlemişlerdir. Bu soruda, formel adaleti başka bir deyişle hukuk içi adaleti gerekli görenlere yönelik üçüncü şıkkın ötekilere kıyasla oldukça yüksek düzeyde işaretlendiği tespit edilmiştir.

Tablo 12: Çukur'un Sonu Ne Olmalıdır Hakkındaki Düşüncelerin Dağılımı

\begin{tabular}{|c|c|c|c|c|}
\hline & Siklık & $\%$ & Geçerli \% & Toplam \% \\
\hline $\begin{array}{l}\text { Devlet Çukur'a müdahale etmeli, düzeni kurmalı } \\
\text { Koçovalı ailesi dahil herkes yargilanmalıdır. }\end{array}$ & 109 & 53 & 53 & 53 \\
\hline $\begin{array}{l}\text { Çukur, çocukluğundan beri eziyet çeken } \\
\text { Vartolu'nun hakimiyetinde girmeli ve yaşamalıdır }\end{array}$ & 17 & 8 & 8 & 61 \\
\hline $\begin{array}{l}\text { Çukur, başındaki tüm dertlerden kurtulmalı, } \\
\text { Koçovalı ailesi hakimiyetini yeniden sağlamalıdır }\end{array}$ & 81 & 39 & 39 & 100,0 \\
\hline Toplam & 207 & 100,0 & 100,0 & \\
\hline
\end{tabular}

Dizinin merkezindeki suç mahallesinin akıbetinin ne olması gerektiğine ilişkin bu soruda, birinci şık adaletin hukuk içi kavranışına, ikinci ve üçüncü şıklarsa adaletin hukuk dışı kavranışına dayandırılacak cevaplar kabul edilmesi öngörülerek hazırlanmıştır. Bu soruya izleyici katılımcıların yaklaşık \% 53'ü birinci, \% 8'i ikinci, \% 39'u ise üçüncü seçeneği işaretleyerek cevap vermişlerdir. $\mathrm{Bu}$ sorudaki ikinci ve üçüncü şılar, yani adaletin gayri hukuki tecellisinin savunulmasına tekabül eden seçenekler toplam \%47 oranında; adaletin hukuk içi sağlanmasına yönelen şıklar ise \%53 oranında tercih edilmiştir. Bu soruda oranların yakın olduğunu görüyoruz fakat gene de hukuk içi adalet şıkkı az bir farkla daha fazla tercih edilmiştir. Fark $\% 5$ de olsa, eğilim ibresinin formel hukuk tarafına yöneldiği söylenebilir. Özetle, Çukur dizisi anketine katılan izleyiciler, adaletin hukuk dahilinde ya da hukukun dışında oluşturması gereğine yönelik soruların büyük bölümünde genellikle \%60'ın üzerinde formel hukuk içi adaleti işaret eden seçeneğe yönelim olduğu gözden kaçmamalıdır. Bunun da izleyicilerin özellikle eğitim durumlarıyla uyumlu bir sonuç olduğu iddia edilebilir.

\section{Cukur Seyircisi ve Islah Edici Ceza}

Dizinin izleyicileri açısından, suçluya öç (intikam) alma hisleriyle acımasızca muameleyi içeren cezalar mı yoksa olabildiğince az zarar vererek bireyleri suçtan uzaklaştırmaya yönelik cezalar mı verilmesi gerektiğine ilişkin oluşturulan soru, hukuk içi-hukuk dış1 adaletin soruşturulduğu, bir önceki bölümde belirtilen sorulardandır. Her iki bağlam açısından da gösterge sayılabilecek bir sorudur: "Kahraman Koçovalı'nın, sübyanc1/istismarcı adamın başını taşla ezmesi hakkında ne düşünüyorsunuz?" şeklindeki soruya verilen cevaplar, Tablo 10'da gösterilmişti. Bu soru, cezanın amacı bakımından yeniden değerlendirilirken, bahsedilen cinayet acımasızca bir eylem olduğundan, formel hukuk dişında olmasına rağmen bunu doğru ve meşru gören birinci seçenek Rahimov'un (2014: 20-27) öç almaya ve kısasa dayanan dinsel bir adalet anlayışına yönelik olarak yorumlanmıştır. Üçüncü seçenek ise (“Allah'ından bulsun”), doğrudan ilahi adalet anlayışına gönderme yapmaktadır. İkinci şıksa esasen direkt olmasa da meseleyi hukuk alanına çekmek bakımından acımasızca öç almak anlayışı yerine suçtan uzak tutma amacını içeren ceza anlayışı 
doğrultusunda yorumlanabilir. Tablo 10'da görüldüğü gibi, bu soruda katılımc1ların \% 65'i intikamc1 olmayan ceza anlayışına tekabül eden ikinci şıkkı işaretlemiştir. Bu izleyicilerin hukuki anlamda formel, toplumsal anlamda seküler yönelimi, modern ceza anlayışının yani cezanın ıslah etmeye ya da rehabilite etmeye yönelik olması gerektiğinin kabul edildiğini gösterir. Bu konu Emile Durkheim'in (Durkheim, 2006) dayanışma tarzlarını merkeze alan modern toplum teorisinin kimi argümanlarını hatırlatmaktadır. Durkheim, Toplumsal İşbölümü çalışmasında mekanik ve organik dayanışma biçimlerini ayrıştırarak modern toplumu teorize ederken, kolektif bilinç kavramını geliştirir. Ona göre, ortak ahlaki bilinç ve duygusal yaşamı ifade eden kolektif bilinç, en açık haliyle sapkınların cezalandırılmasında gözlenebilir. Modern toplumları, herkesin farklı işi yapması ve uzmanlık geliştirmesi, işbölümüne göre örgütlenmesi yani organik dayanışma karakterize eder ve modern toplum, cezanın amacını bireyin grupla yeniden bütünleştirilmesi olarak görür. Bir başka deyişle modernitede ceza, topluma kazandırma, rehabilite etme amacını taşır. Mekanik dayanışmada ise ceza, suçu ve bunu işleyen sapkını yok etmeye yönelir. Çukur izleyicilerinin, cezayı hukuk içinde ve topluma kazandırma amacını taşır şekilde görmelerinin, modern bir yorumlamaya, adalet anlayışları açısından moderniteyle uyumlu bir konumlanmaya tekabül ettiğini söyleyebiliriz.

\section{Çukur Seyircisi ve Suçun Toplumsallı̆̆}

Dizi karakterlerinden Vartolu Saadettin'in neden suç işlediğine ilişkin soruda, birinci şık suçun sorumluluğunu kişisel sayan, ikinci, üçüncü ve dördüncü şılar ise tersine, hayat şartlarının etkisiyle gerçekleştiğini kabul edenleri öngörerek hazırlanmıştır.

Tablo 13: Vartolu Neden Suç İşler Dağılım

\begin{tabular}{l|r|r|r|r} 
& Sıklı & \% & Geçerli \% & Toplam \% \\
\hline Psikopat ve kötü biri olduğundan & 8 & 4 & 4 & 4 \\
\hline Çocukluğundan itibaren yaşadıklarının etkisiyle & 155 & 75 & 75 & 79 \\
\hline Aile eksikliğinden & 36 & 17 & 17 & 96 \\
\hline Eğitim alamadığından & 8 & 4 & 4 & 100,0 \\
\hline Toplam & 207 & 100,0 & 100,0 & \\
\hline
\end{tabular}

Vartolu karakterinin neden suç işlediğine ilişkin bu soruda, izleyici katılımcıların yaklaşık \% 4'ü "psikopat" ve "kötü" biri olduğundan, \% 75'i çocukluğundan başlayarak yaşadıklarının etkilerinden, \% 17'si aile eksikliğinden, \%4'ü ise eğitimsiz olduğu için suç işlediğini düşünmüştür. Dolayısıyla suçun sorumluluğunun kişisel olduğuna ilişkin şıkkı tercih etme oranı çok düşük olmuştur.

Tablo 14: Çukur Halkı Neden Suç İşler Hakkındaki Düşüncelerin Dağılımı

\begin{tabular}{l|r|r|r|r} 
& S1klık & $\%$ & Geçerli \% & Toplam \% \\
\hline $\begin{array}{l}\text { Suç düzenine ayak uydurmak kendi } \\
\text { tercihleridir }\end{array}$ & 74 & 36 & 36 & 36 \\
\hline $\begin{array}{l}\text { İçine doğdukları şartlardan dolayı suçla } \\
\text { yaşamak zorundadırlar }\end{array}$ & 133 & 64 & 64 & 100,0 \\
\hline \begin{tabular}{l} 
Toplam \\
\hline
\end{tabular} & 207 & 100,0 & 100,0 & \\
\hline
\end{tabular}

“Çukur'da yaşayan ailenin ve mahallelinin işledikleri suçlar hakkında ne düşünürsünüz?” sorusunda birinci şık suçun altında yer alan güdülerin ve suçun sorumluluğunun kişisel, ikinci şık ise toplumsal olduğunu kabul edenleri tespit için hazırlanmıştır. Bu soruda, yaklaşı \%36 oranında birinci, \% 64 seviyesinde ise ikinci şıkta yoğunlaşılmıştır. Benzer şekilde suçun sorumluluğunun yapısal ve toplumsal yönlerini öne çıkaran seçeneğin epey yüksek oranda işaretlendiği görülmektedir. Çukur dizisi izleyicilerinin, oldukça güçlü bir şekilde suçun toplumsal nedenlerini gözetenlerden oluştuğu anlaşılmaktadır. 


\section{Adalet Soru ve Yanıtlarının Gösterdikleri: Egemen ve Muhalif Okumalar}

Dizi kahramanlarının kimliği ile ilgili sorulara verilen yanıtlara göre, Çukur dizisini takip eden katılımcıların \% 45'e yakını, mahalleye hükmeden Koçovalı ailesinin, halihazırda dizide de kahraman olarak kodlanan, küçük oğlu Yamaç Koçovalı'yı kahraman olarak görmüş, \% 32'si ise bir tür anti-kahraman olarak kodlanan, Vartolu Saadettin'i "kahraman"ları olarak belirlemek suretiyle bir anlamda muhalif okuma yapmıştır.

Araştırmanın yapıldığı ana kadar yayınlanmış bölümlerin anlatısı içinde kahraman olarak kodlanmış karakterler dışındaki karakterlerin de kahraman olarak belirtilmiş olması, dizi kahramanı hususunda karşıt okumalar yapıldığını göstermektedir. İzleyicilerin \% 60'ından çoğu, adaletin hukuksal veya gayri hukuk sağlanması gereğine ilişkin soruların hemen hepsinde, hukuk içi adaleti vurgulayan seçenekleri işaretlemişlerdir. Çukur dizisinde anlatının incelendiğinde, hukuk dışı adaletin büyük oranda olağan / baskın anlam olarak sunulduğu görülmektedir. Çukur bir suç dizisi olarak, suçlu karakterlerin günlük yaşamın formel hukuk alanı haricindeki gelişen eylemleri durumlarını işler. Öte yandan söz konusu eylemler dizi anlatısında olumsuz bir şekilde sunulmamaktadır. Dizide hakim kod suçun normalliği üzerinedir, anlatıda hakim kod adaletin hukuk sınırları dışında sağlanmaya çalışıldığı bir nizama ilişkin anlamlar üzerine inşa edilmiştir. Hall'den hareketle, metnin hukuk dışı bir adalet kavrayışına göre kodlanmış olduğu söylenebilir. Bu durumda, hukuk içi adalet anlayışını imleyen seçeneklere yönelenler, dizi anlatısının muhalif bir okumasını yapmış olmaktadırlar. Çukur dizisi anketi katılımcılarının genel durumuna ele alındığında, görece yüksek düzeyde hukuk içi adaleti içeren şıkları tercih etmesi, göreli olarak yüsek seviyede muhalif anlamlandırmalar (okumalar) yapıldığını göstermektedir.

Çukur dizisi izleyici anketinde, cezanın intikam almaya ya da olası minumum az zararla en yüksek oranda caydırmaya mı yönelik olduğuna ilişkin soruya, \%60'1n üzerinde katılımcı intikamcı olmayan, toplumun suçtan uzaklaştırmak amacına hizmet eden cezayı uygun kabul ettiklerini ortaya koymuşlardır. Çukur dizisinin hakim anlatısının, intikamcı ve gaddar (insani olmayan) cezaların haklı gösterilmesine dayanan bir adalet anlayışı üzerine kurulu olduğu söylenebilir. Ancak katılımcılar verdikleri cevaplarla oldukça yüksek oranda, bu kodlamaya muhalif bir okuma gerçekleştirdiklerini göstermişlerdir.

Suçun kişisel mi, yoksa toplumsal etkenlere bağlı mı olduğuna ilişkin sorularda, yüksek oranlara tekabül eden oranda suçun toplumsal boyutlarına ilişkin bir bilinci gündeme getiren seçenekler işaretlenmiştir. Dizinin anlatısı incelendiğinde, suçun temelinde yatan unsurlar ve suçun mesuliyetinin kişisel veya toplumsallığına ilişkin hakim kodun, suçların gerisindeki toplumsal ve çevresel koşulları gözardı etmeyecek şekilde kurulduğu görülmektedir. Bu bağlamda, dizinin izleyicilerinin, daha fazla egemen okuma yapmış oldukları söylenebilir. Sadece Vartolu Saadettin'in suçluluğunun nedenlerine dair soruda, hakim kodlama çevresel koşulların etkisinden yana olsa da, kendi psikopatik kişilik özellikleri de etkenler arasında sayılmaktadır. Bu anlamda, çift anlamlılığın söz konusu olduğu anlatıda, seyircilerin büyük kısmı gene suçun toplumsal yönlerini öne çıkaran seçenekler lehine tercih kullanmışlardır.

Söz konusu hakim ve karşıt okuma tarzları, ilk başlıklarda dile getirildiği üzere, Hall'ün medya metninde kodlanmış hakim anlamlara ilişkin olarak, izleyicilerin hakim anlamlar çerçevesinde yeğlenen-hakim okuma tarzı ile beraber, iç içe geçmiş kültürel anlam çerçeveleri doğrultusunda, metni kısmen hakim anlatıda kodlanan doğrultuda, kısmen ise bu kodlanan anlamlara muhalif olarak müzakereci bir okuma yapma veya hakim-yeğlenen anlamların zıttı doğrultusunda tam bir muhalif okuma yapma olanaklarını ortaya koyduğu kavramsal çerçevesi ile adalete ilişkin araştırma eksenleri bağlamında adalet kavramsallaştırmasının göreli olduğuna ilişkin bakış açısının yan yana değerlendirilebileceğini ve adaletin göreliliğinin, medya metnini alımlama olanak ve biçimlerinin çeşitliliği ile örtüştüğünü göstermiştir. 


\section{İzleyici ve Adalet Kavrayışları: Demografik Değişkenler Bağlamında}

\section{Çukur Dizisi ve Hukuk İçi - Hukuk Dışı Adalet}

"Uyuşturucu hariç her türlü suçun işlendiği fakat polisini giremediği Koçova Mahallesi hakkında ne düşünürsünüz?" sorusu adaletin hukuk içinde ve yahut hukuk dışında sağlanması ile ilgili tutumları ölçmeye yöneliktir. Seçenekleri ise, "1. Çukur bir suç mahallesidir. 2. Çukur adil/adaletli bir mahalledir. 3. Diğer:...” şeklindedir.

$\mathrm{Bu}$ soruya ilişkin birinci seçenek, adaletin hukuk içi algılandığını, ikinci şık ise adaletin hukuk-dışı algılandığını imlemektedir. Bu soruya verilen yanıtların, toplumsal cinsiyet, yaş, medeni hal, meslek eğitim, gelir durumu ve dünya görüşü değişkenlerine göre dağılımı, tablolarda görülmektedir:

Tablo 15: Cinsiyet - Koçova Hakkında Düşünce

\begin{tabular}{|c|c|c|c|c|c|c|}
\hline & & & $\begin{array}{c}\text { Bir suç } \\
\text { mahallesidir }\end{array}$ & $\begin{array}{l}\text { Adil/Adaletli } \\
\text { bir mahalledir }\end{array}$ & Diğer & Toplam \\
\hline \multirow{8}{*}{ Cinsiyet } & \multirow{4}{*}{ Erkek } & Sayı & 62 & 32 & 8 & 102 \\
\hline & & \% Cinsiyet içinde & $61 \%$ & $31 \%$ & $8 \%$ & $100 \%$ \\
\hline & & \% Bu soru içinde & $45 \%$ & $62 \%$ & $47 \%$ & $49 \%$ \\
\hline & & \% Toplam içinde & $30 \%$ & $16 \%$ & $4 \%$ & $49 \%$ \\
\hline & \multirow{4}{*}{ Kadın } & Sayı & 76 & 20 & 9 & 105 \\
\hline & & $\%$ Cinsiyet içinde & $72 \%$ & $19,0 \%$ & $9 \%$ & $100 \%$ \\
\hline & & $\% \mathrm{Bu}$ soru içinde & $55 \%$ & $39 \%$ & $53 \%$ & $51 \%$ \\
\hline & & \% Toplam içinde & $37 \%$ & $10 \%$ & $4 \%$ & $51 \%$ \\
\hline \multirow[t]{3}{*}{ Toplam } & & Sayı & 138 & 52 & 17 & 207 \\
\hline & & $\% \mathrm{Bu}$ soru içinde & $100,0 \%$ & $100,0 \%$ & $100,0 \%$ & $100 \%$ \\
\hline & & \% Toplam içinde & $67 \%$ & $25 \%$ & $8 \%$ & $100 \%$ \\
\hline
\end{tabular}

Cinsiyete değișkeni düşünüldüğünde, tabloda görüldüğü üzere Cukur dizisi anketi katılımcılarının \% 49'na denk düșen erkek izleyici katılımcılardan \% 61'i Koçova Mahallesi'nin (Çukur) bir suç ortamı olduğu kanaatindedir. Katılımcı erkeklerin \% 31'i "adil/adaletli bir mahalledir" seçeneğini, \% 8'i ise "diğer" şıkkını doldurmuştur. "Diğer" şıkkına yönelenler incelendiğinde, her iki yanıtı da kabul etmemekle birlikte, yerine başka bir yanıt önermeyen veya yanıt olarak "Bir mahalledir" biçiminde, her hangi sıfat ifade etmeyen seyirci olduğu gibi, hem bir suç mahallesi hem de adil/adaletli bir mahalle olduğunu iddia edenlerin de olduğu görülmüştür. Çukur'un adaletli bir mahalle olduğu yanıtını yetersiz bulan bir katılımeı ise, hem adaletli bir mahalle olduğuna ek olarak kendi mahallesine benzediğini belirtme ihtiyacı duymuştur. Diğer seçeneğine yönelenler içinde Çukur'u gerçekçi bir mahalle olarak tanımlayanlar da olmuştur.

Bütün izleyici katılımcıların \% 50,7'sini oluşturan kadın katılımcılardan \% 72'si Çukur'un bir suç mahallesi olduğunu imleyen birinci seçeneği işaretlerken, \% 19'u ise Çukur'un adil/adaletli bir mahalle olarak görmüştür. Katılımcı kadınların \% 9'u ise "diğer" şıkkını seçmiştir. Çukur'un bir suç mahallesi olduğuna ilișkin yanıtı yetersiz bulmuş olanlardan bazıları, Çukur'un "kötü bir mahalle" olduğunu kendi kelimeleriyle eklemişlerdir. Suçlar arasında hiyerarşi kurmak suretiyle, diziyi gerçek hayatla birebir örtüştüremediği için bu tür görüş bildirmeyeceğini belirten; silah kaçakçılığının suç olduğunu kabul etmekle birlikte tecavüz, çocuk cinayeti vs. suçlar mevcut olmadığı için, bu yönüyle olumlu bir yanı olduğunu, tamamen suç mahallesi olarak yaftalamak istemediğini belirtenler de vardır

Tabloda görüleceği üzere, Çukur'un bir suç mahallesi olduğu fikrindeki kadınların oranı erkeklerden yaklaşık \% 12 fazladır. Bu ek olarak, Çukur'un ne tür bir mahalle olduğu hakkındaki fikirleri tespit etmeye yönelik bu soruya ilişkin "diğer" seçeneğini işaretleyerek kendi açıklamalarını ekleyen erkeklerle kadınların yaklaşımları ve verdikleri cevaplar da oldukça farklıdır. Katılımcı 
erkekler Çukur'un iyi bir mahalle olduğu yönünde ifadeler içeren yanıtlar verirken; kadınlarsa çoğunlukla Çukur'un kötü bir mahalle olduğu yönünde ifadeler içeren cevaplar dile getirmiştir.

Mahallenin ahlaki karakteri hakkındaki tutumları ölçen bu sorunun her iki şıkk için de cinsiyet değişkenine göre dağılımlar değerlendirildiğinde, Çukur'u bir suç mahallesi olarak tanımlayanların \% 45'inin erkek, \% 55'inin kadın olduğu fark edilmektedir. Bunun yanı sıra Çukur'un adil/adaletli bir mahalle olduğu kanaatindekilerin \% 62's'i erkek ve \% 39'u kadındır. Her iki açıdan da, kadınların erkeklerle kıyaslandığında daha yüksek düzeyde Çukur'u bir suç mahallesi saydıkları görülmektedir.

Tablo 16: Yaş - Koçova Hakkında Düşünce

\begin{tabular}{|c|c|c|c|c|c|c|}
\hline & & & $\begin{array}{l}\text { Bir suç } \\
\text { mahallesidir. }\end{array}$ & $\begin{array}{c}\text { Adil/Adaletli bir } \\
\text { mahalledir. }\end{array}$ & Diğer & Toplam \\
\hline & 18 & Sayı & 3 & 7 & 0 & 10 \\
\hline & yaşından & \% Yaş içinde & $30 \%$ & $70 \%$ & $0,0 \%$ & $100 \%$ \\
\hline & küçük & \% Toplam içinde & $2 \%$ & $4 \%$ & $0,0 \%$ & $5 \%$ \\
\hline & $18-25$ & Say1 & 45 & 20 & 6 & 71 \\
\hline & yaş arası & \% Yaş içinde & $63 \%$ & $28 \%$ & $9 \%$ & $100 \%$ \\
\hline & & \% Toplam içinde & $22 \%$ & $10 \%$ & $3 \%$ & $34 \%$ \\
\hline & $25-35$ & Sayı & 69 & 21 & 11 & 101 \\
\hline & yaş arası & \% Yaş içinde & $68 \%$ & $21 \%$ & $11 \%$ & $100 \%$ \\
\hline & & \% Toplam içinde & $33 \%$ & $10 \%$ & $5 \%$ & $49 \%$ \\
\hline & $35-45$ & Say1 & 14 & 2 & 0 & 16 \\
\hline & yaş arası & \% Yaş içinde & $88 \%$ & $13 \%$ & $0,0 \%$ & $100 \%$ \\
\hline & & \% Toplam içinde & $7 \%$ & $1 \%$ & $0,0 \%$ & $8 \%$ \\
\hline & $45-55$ & Sayı & 7 & 1 & 0 & 8 \\
\hline Yaş & yaş arası & \% Yaş içinde & $88 \%$ & $13 \%$ & $0,0 \%$ & $100,0 \%$ \\
\hline & & \% Toplam içinde & $3 \%$ & $0,5 \%$ & $0,0 \%$ & $4 \%$ \\
\hline & $55-65$ & Sayı & 0 & 1 & 0 & 1 \\
\hline & yaş arası & \% Yaş içinde & $0,0 \%$ & $100 \%$ & $0,0 \%$ & $100 \%$ \\
\hline & & \% Toplam içinde & $0,0 \%$ & $0,5 \%$ & $0,0 \%$ & $0,5 \%$ \\
\hline Top & & Sayı & 138 & 52 & 17 & 207 \\
\hline & & \% Toplam içinde & $67 \%$ & $25 \%$ & $8 \%$ & $100 \%$ \\
\hline
\end{tabular}

Bu konudaki cevapların yaşa göre dağılımını içeren tabloya bakıldığında, yaş aralıkları hususunda katılımcıların homojen bir dağılıma sahip olmadıkları görülür. Yaş aralığı18-25 ve 25-35 arasındaki izleyici katılımcılar, bütün izleyici sayısının \% 83'nü oluşturmaktadır. Toplam izleyici katılımcıların ağırlıklı kısmını 18-35 yaş aralığındakiler oluşturmaktadır. Bunlar içinde karşılaştırma yapılırsa, 18-25 yaş aralığındakilerden Çukur'un bir suç mahallesi olduğunu düşünenlerin oranı \% 63'tür ve 25-35 yaş grubunda ise bu kanaatte olanların \%68 olduğu görülecektir. Katılımcıların önemli bir kısmını oluşturan bu iki yaş grubunda, Çukur'un bir suç mahallesi olduğunu düşünenlerin sayısı, yaş ile doğru orantılı olarak çok az artmıştır. Diğer yaş gruplarında ise bu seçeneği işaretleme oranının, yaş ilerledikçe daha belirgin şekilde yükselmiştir. Her yaş grubundaki katılımcı sayısının, cinsiyet gruplarında olduğu gibi birbirine yakın olmasının daha sağlıklı bir kıyaslama yapılabilmesini sağladığı bilinse de, ulaşılabilenlerden diziyi izleyenlerin çoğunlukla18-35 yaş aralığında olması araştırmanın seyrinde kendiliğinden gelişen bir sınırlılık ortaya çıkardığından, yaş aralıkları bakımından homojen katılımcı dağılımı sağlanamamıştır. Mevcut tabloya göre, yaş yükseldikçe Çukur'un suç mahallesi olduğu yönündeki yargıyı destekleme oranı artmaktadır. 
Tablo 17: Eğitim Durumu - Koçova Hakkında Düşünce

\begin{tabular}{|c|c|c|c|c|c|c|}
\hline & & & $\begin{array}{c}\text { Bir suç } \\
\text { mahallesidir. }\end{array}$ & $\begin{array}{c}\text { Adil/Adaletli } \\
\text { bir mahalledir }\end{array}$ & Diğer & Toplam \\
\hline \multirow{12}{*}{$\begin{array}{l}\text { İzleyicilerin } \\
\text { Eğitim } \\
\text { Durumu }\end{array}$} & \multirow{4}{*}{$\begin{array}{l}\text { Düşük } \\
\text { Eğitimli }\end{array}$} & Sayı & 5 & 10 & 1 & 16 \\
\hline & & \% Eğitim içinde & $31 \%$ & $63 \%$ & $6 \%$ & $100 \%$ \\
\hline & & $\%$ Bu soru içinde & $4 \%$ & $19 \%$ & $6 \%$ & $8 \%$ \\
\hline & & \% Toplam içinde & $2 \%$ & $5 \%$ & $0,5 \%$ & $8 \%$ \\
\hline & \multirow{4}{*}{$\begin{array}{l}\text { Orta } \\
\text { Eğitimli }\end{array}$} & Sayı & 16 & 19 & 2 & 37 \\
\hline & & \% Eğitim içinde & $43 \%$ & $51 \%$ & $5 \%$ & $100 \%$ \\
\hline & & $\%$ Bu soru içinde & $12 \%$ & $37 \%$ & $12 \%$ & $18 \%$ \\
\hline & & \% Toplam içinde & $8 \%$ & $9 \%$ & $1 \%$ & $18 \%$ \\
\hline & \multirow{4}{*}{$\begin{array}{l}\text { Yüksek } \\
\text { Eğitimli }\end{array}$} & Sayı & 117 & 23 & 14 & 154 \\
\hline & & \% Eğitim içinde & $76 \%$ & $15 \%$ & $9 \%$ & $100 \%$ \\
\hline & & \% Bu soru içinde & $85 \%$ & $44 \%$ & $82 \%$ & $74 \%$ \\
\hline & & \% Toplam içinde & $57 \%$ & $11 \%$ & $7 \%$ & $74 \%$ \\
\hline \multirow[t]{3}{*}{ Toplam } & & Sayı & 138 & 52 & 17 & 207 \\
\hline & & $\%$ Bu soru içinde & $100 \%$ & $100 \%$ & $100 \%$ & $100 \%$ \\
\hline & & $\%$ Toplam içinde & $67 \%$ & $25 \%$ & $8 \%$ & $100 \%$ \\
\hline
\end{tabular}

Söz konusu soruya verilen yanıtların eğitim düzeyi değişkenine göre dağılımını gösteren tablo incelendiğinde, "Bir suç mahallesidir." seçeneğini düşük eğitim düzeyine sahip katılımcıların işaretleme oranının $\% 31$, orta düzeyde eğitimli katılımcıların işaretleme oranının $\% 43$, yüksek eğitimli katılımcıların işaretleme oranının ise \%76 olduğu gözlenmektedir. "Adil/Adaletli bir mahalledir." Olarak tanımlanan bir diğer seçeneği işaretleme oranı da düşük eğitim düzeyindeki katılımc1larda $\% 63$, orta eğitim düzeyindeki katılımcılarda $\% 51,4$ iken, yüksek düzeyindeki kat1lımcilarda ise $\% 15$ 'dir.

Eğitim düzeyinde de, yaş ve medeni durumla ilgili değişkenlerindeki gibi izler kitle grupları birbirlerine yakın sayıda değilse de (düşük eğitim düzeyindekiler: \%8 orta eğitim düzeyindekiler: \%18 yüksek eğitim düzeyindekiler: \%74) eğitim düzeyi yükseldikçe, her eğitim düzeyi grubunun kendi içinde Çukur'un suç mahallesi olduğu yolundaki ifadelerin oranı da artmaktadır. Buna bağlı olarak, eğitim düzeyi yükseldikçe Çukur'un adaletli bir mahalle olduğu düşüncesi dile getirenlerin oranı da azalmaktadır. Eğitim düzeyi değişkeni hesaba katıldığında, bu sorunun cevapları, diğer değişkenlerdeki kadar düşük düzeylerde değil, önemli ve dikkat çekici oranda farklılaşmıştır.

Tablo 18: Meslek - Koçova Hakkında Düşünce

\begin{tabular}{|c|c|c|c|c|c|}
\hline & & $\begin{array}{c}\text { Bir suç } \\
\text { mahallesidir. }\end{array}$ & $\begin{array}{c}\text { Adil/Adaletli } \\
\text { bir mahalledir. }\end{array}$ & Diğer & Toplam \\
\hline \multirow[t]{4}{*}{ Esnaf } & Sayı & 4 & 4 & 0 & 8 \\
\hline & \% Meslek içinde & $50 \%$ & $50 \%$ & $0,0 \%$ & $100 \%$ \\
\hline & $\%$ Bu soru içinde & $3 \%$ & $8 \%$ & $0,0 \%$ & $4 \%$ \\
\hline & $\%$ Toplam içinde & $2 \%$ & $2 \%$ & $0,0 \%$ & $4 \%$ \\
\hline \multirow[t]{4}{*}{ Sanatçı } & Sayı & 4 & 2 & 0 & 6 \\
\hline & $\%$ Meslek içinde & $67 \%$ & $33 \%$ & $0,0 \%$ & $100 \%$ \\
\hline & $\%$ Bu soru içinde & $3 \%$ & $4 \%$ & $0,0 \%$ & $3 \%$ \\
\hline & \% Toplam içinde & $2 \%$ & $1 \%$ & $0,0 \%$ & $3 \%$ \\
\hline \multirow[t]{4}{*}{ Ev Hanımı } & Say1 & 11 & 3 & 1 & 15 \\
\hline & $\%$ Meslek içinde & $73 \%$ & $20 \%$ & $7 \%$ & $100 \%$ \\
\hline & $\%$ Bu soru içinde & $8 \%$ & $6 \%$ & $6 \%$ & $7 \%$ \\
\hline & \% Toplam içinde & $5 \%$ & $1 \%$ & $0,5 \%$ & $7 \%$ \\
\hline İşçi & Say1 & 12 & 7 & 1 & 20 \\
\hline
\end{tabular}




\begin{tabular}{|c|c|c|c|c|c|c|}
\hline \multirow{23}{*}{ Meslek } & & \% Meslek içinde & $60,0 \%$ & $35,0 \%$ & $5,0 \%$ & $100,0 \%$ \\
\hline & & $\% \mathrm{Bu}$ soru içinde & $8,7 \%$ & $13,5 \%$ & $5,9 \%$ & $9,7 \%$ \\
\hline & & $\%$ Toplam içinde & $5,8 \%$ & $3,4 \%$ & $0,5 \%$ & $9,7 \%$ \\
\hline & \multirow[t]{4}{*}{ Öğrenci } & Say1 & 38 & 13 & 7 & 58 \\
\hline & & $\%$ Meslek içinde & $65,5 \%$ & $22,4 \%$ & $12,1 \%$ & $100,0 \%$ \\
\hline & & $\%$ Bu soru içinde & $27,5 \%$ & $25,0 \%$ & $41,2 \%$ & $28,0 \%$ \\
\hline & & $\%$ Toplam içinde & $18,4 \%$ & $6,3 \%$ & $3,4 \%$ & $28,0 \%$ \\
\hline & \multirow[t]{4}{*}{ Memur } & Say1 & 23 & 5 & 2 & 30 \\
\hline & & $\%$ Meslek içinde & $76,7 \%$ & $16,7 \%$ & $6,7 \%$ & $100,0 \%$ \\
\hline & & $\%$ Bu soru içinde & $16,7 \%$ & $9,6 \%$ & $11,8 \%$ & $14,5 \%$ \\
\hline & & \% Toplam içinde & $11,1 \%$ & $2,4 \%$ & $1,0 \%$ & $14,5 \%$ \\
\hline & \multirow[t]{4}{*}{ Emekli } & Sayı & 0 & 1 & 0 & 1 \\
\hline & & $\%$ Meslek içinde & $0,0 \%$ & $100 \%$ & $0,0 \%$ & $100 \%$ \\
\hline & & \% Bu soru içinde & $0,0 \%$ & $2 \%$ & $0,0 \%$ & $0,5 \%$ \\
\hline & & \% Toplam içinde & $0,0 \%$ & $0,5 \%$ & $0,0 \%$ & $0,5 \%$ \\
\hline & \multirow[t]{4}{*}{ İşsiz } & Say1 & 15 & 4 & 2 & 21 \\
\hline & & \% Meslek içinde & $71 \%$ & $19 \%$ & $10 \%$ & $100 \%$ \\
\hline & & $\% \mathrm{Bu}$ soru içinde & $11 \%$ & $8 \%$ & $12 \%$ & $10 \%$ \\
\hline & & $\%$ Toplam içinde & $7 \%$ & $2 \%$ & $1 \%$ & $10 \%$ \\
\hline & \multirow[t]{4}{*}{ Diğer } & Sayı & 31 & 13 & 4 & 48 \\
\hline & & \% Meslek içinde & $65 \%$ & $27 \%$ & $8 \%$ & $100 \%$ \\
\hline & & $\%$ Bu soru içinde & $23 \%$ & $25 \%$ & $24 \%$ & $23 \%$ \\
\hline & & $\%$ Toplam içinde & $15 \%$ & $6 \%$ & $2 \%$ & $23 \%$ \\
\hline \multirow[t]{2}{*}{ Toplam } & & Say1 & 138 & 52 & 17 & 207 \\
\hline & & $\%$ Toplam içinde & $67 \%$ & $25 \%$ & $8 \%$ & $100 \%$ \\
\hline
\end{tabular}

Mahallenin adilliği ya da suç yuvası olmasıyla ilgili sorunun mesleklere göre dağılımı tablosundan da görüldüğü meslekler bakımından homojen bir dağılım yoktur. Bu soruya dair seçenekler de açıkça sınıfsal bir farka işaret edecek seçenekler değildir. Bu nedenlerle, mesleklere göre bu soruya verilen yanıtlardaki oran farklılıklarını mutlak derecede anlamlı bir farklılık olarak yorumlamak sorunlu da olsa, bilhassa öğrenci, memur ve ev kadınlarının \%70'in üzerinde Çukur mahallesi ile ilgili "Bir suç mahallesidir." yargısını desteklediklerini vurgulamak gerekmektedir. Bunun yanısıra, mesleğini "öğrenci" olarak belirtenlerin \% 81'inin öğrenim durumunu üniversite veya lisansüstü eğitimi olarak belirtmişleridir. Tablo, katılımcıların eğitim seviyesi arttıkça, Çukur'un bir suç mahallesi olduğu yargısını destekleme oranının yükseldiği göstermektedir. Öğrencilerin ekseriyetinin, yüksek öğrenim seviyesinde oldukları hesaba katıldığında, öğrencilerin de Çukur'a dair olumsuz yargılarının, eğitim düzeyleri ile doğru orantılı olduğu görülmektedir. Benzer bir şekilde, kadınların erkeklere kıyasla daha yüksek oranda bu seçeneği işaretledikleri görülmüştü. Buna ek olarak, ev kadınlarının da \%70'in üzerinde, benzer seçeneğe yönelen diğer üç meslek grubundan biri olarak öne çıktığı görülmektedir. 
Tablo 19: Gelir Durumu - Koçova Hakkında Düşünce

\begin{tabular}{|c|c|c|c|c|c|c|}
\hline & & & $\begin{array}{c}\text { Bir suç } \\
\text { mahallesidir }\end{array}$ & $\begin{array}{l}\text { Adaletli bir } \\
\text { mahalledir }\end{array}$ & Diğer & Toplam \\
\hline \multirow{12}{*}{$\begin{array}{l}\text { Gelir } \\
\text { Durumu }\end{array}$} & \multirow{4}{*}{$\begin{array}{l}\text { Çok } \\
\text { düşük } \\
\text { gelirli }\end{array}$} & Say1 & 19 & 11 & 5 & 35 \\
\hline & & \% Gelir durumu içinde & $54 \%$ & $31 \%$ & $14 \%$ & $100 \%$ \\
\hline & & $\%$ Bu soru içinde & $13 \%$ & $21 \%$ & $29 \%$ & $17 \%$ \\
\hline & & $\%$ Toplam içinde & $9 \%$ & $5 \%$ & $2 \%$ & $17 \%$ \\
\hline & \multirow{4}{*}{$\begin{array}{l}\text { Düşük } \\
\text { gelirli }\end{array}$} & Say1 & 95 & 36 & 9 & 140 \\
\hline & & \% Gelir durumu içinde & $68 \%$ & $26 \%$ & $6 \%$ & $100 \%$ \\
\hline & & $\%$ Bu soru içinde & $69 \%$ & $69 \%$ & $53 \%$ & $68 \%$ \\
\hline & & \% Toplam içinde & $46 \%$ & $17 \%$ & $4 \%$ & $68 \%$ \\
\hline & \multirow{4}{*}{$\begin{array}{l}\text { Normal } \\
\text { sinır ve } \\
\text { üstü }\end{array}$} & Say1 & 24 & 5 & 3 & 32 \\
\hline & & $\%$ Gelir durumu içinde & $75 \%$ & $16 \%$ & $9 \%$ & $100 \%$ \\
\hline & & \% Bu soru içinde & $17 \%$ & $10 \%$ & $18 \%$ & $16 \%$ \\
\hline & & $\%$ Toplam içinde & $12 \%$ & $2 \%$ & $1 \%$ & $16 \%$ \\
\hline \multirow[t]{2}{*}{ Toplam } & & Say1 & 138 & 52 & 17 & 207 \\
\hline & & $\%$ Toplam içinde & $67 \%$ & $25 \%$ & $8 \%$ & $100 \%$ \\
\hline
\end{tabular}

Bu tabloda, katılımcıların ailelerinin gelir durumları hesaba katıldığında, söz konusu soruya verdikleri yanıtların dağılımı görülmektedir. Çok düşük geliri olduğunu belirtenlerin \%54'ü Çukur'u "bir suç mahallesi" olarak görmektedir. Görece biraz daha fazla geliri olan"düşük gelirli" grubunda yer alan kişilerin ise \%68 oranında aynı seçeneği işaretlediği göze çarpmaktadır. "Normal ve üstü gelir" diye gruplandırılanların ise \% 75'inin mahalleyi suç ile tanımladığı sonucuna ulaşılmıştır. Katılımcıların gelir durumları düşünüldügünde, en fazla sayıda seyircinin yer aldığı gelir grubu "orta gelirliler" (\%68) olmasına rağmen, her gelir grubu kendi içinde de ayrı olarak ele alındığında, gelir seviyesinin yükselmesiyle Çukur'u suç ile etiketleme yöneliminin yoğunlaştığı gözlenmektedir. Benzer bir biçimde, bu seçeneğin zıttı olarak düşünülmüş "Adaletli bir mahalledir." seçeneğinin işaretlenme oranı da gelir arttıkça azalmaktadır.

Tablo 20: Dünya Görüşü - Koçova Mahallesi Hakkındaki Düşünceler

\begin{tabular}{|c|c|c|c|c|c|c|}
\hline & & & $\begin{array}{c}\text { Bir suç } \\
\text { mahallesidir }\end{array}$ & $\begin{array}{c}\text { Adil/Adaletli } \\
\text { bir mahalledir }\end{array}$ & Diğer & Toplam \\
\hline \multirow{12}{*}{$\begin{array}{l}\text { Dünya } \\
\text { Görüşü }\end{array}$} & \multirow{4}{*}{$\begin{array}{l}\text { Sağ } \\
\text { görüşlüler }\end{array}$} & Say1 & 55 & 27 & 6 & 88 \\
\hline & & \% Dünya görüşü içinde & $63 \%$ & $31 \%$ & $7 \%$ & $100 \%$ \\
\hline & & $\% \mathrm{Bu}$ soru içinde & $40 \%$ & $52 \%$ & $35 \%$ & $43 \%$ \\
\hline & & \% Toplam içinde & $27 \%$ & $13 \%$ & $3 \%$ & $43 \%$ \\
\hline & \multirow{4}{*}{$\begin{array}{l}\text { Sol } \\
\text { görüşlüler }\end{array}$} & Say1 & 73 & 21 & 5 & 99 \\
\hline & & \% Dünya görüşü içinde & $74 \%$ & $21 \%$ & $5 \%$ & $100 \%$ \\
\hline & & $\% \mathrm{Bu}$ soru içinde & $53 \%$ & $40 \%$ & $29 \%$ & $48 \%$ \\
\hline & & \% Toplam içinde & $35 \%$ & $10 \%$ & $2 \%$ & $48 \%$ \\
\hline & \multirow[t]{4}{*}{ Diğer } & Say1 & 10 & 4 & 6 & 20 \\
\hline & & \% Dünya görüşü içinde & $50 \%$ & $20 \%$ & $30 \%$ & $100 \%$ \\
\hline & & $\%$ Bu soru içinde & $7 \%$ & $8 \%$ & $35 \%$ & $10 \%$ \\
\hline & & \% Toplam içinde & $5 \%$ & $2 \%$ & $3 \%$ & $10 \%$ \\
\hline \multirow[t]{2}{*}{ Toplam } & & Say1 & 138 & 52 & 17 & 207 \\
\hline & & \% Toplam içinde & $67 \%$ & $25 \%$ & $8 \%$ & $100 \%$ \\
\hline
\end{tabular}

$\mathrm{Bu}$ soruya verilen yanıtların, dünya görüşü değiş̧kenine göre dağılımı, tabloda gösterilmektedir. Söz konusu ayırım ile sağ görüşlüler başlığı altındaki dünya görüşü katılımcı sayısı şıkkını seçen 88, sol görüşlüler olarak tanımlanabilecek katılımcı sayısı ise 99'dur. Önceki değişkenler düşünüldüğünde, birbirine en yakın sayıda katılımcı içeren başlıklar, sol ve sağ görüşlüler başılşarı olmuştur. Bu nedenle yapılacak herhangi bir karşılaştırmanın görece isabetli 
olabileceği söylenebilir. Dünya görüşüne tespit etmeye yönelik soruya, verili seçenekleri işaretlemek yerine "diğer" cevabını veren ve şıklardan bağımsız olarak yazılı belirten toplam 20 kişi olmuştur. Söz konusu 20 kişi, toplam cevaplayıcı sayısının \%10'unu oluşturmaktadır.

Dünya görüşü değişkeni hesaba katıldığında, sağ görüşe sahip olanların Çukur'u "Bir suç mahallesidir" olarak tanımlama oran $\%$ 63, sol görüşlülerin ise \% 74'dür. Bunun yanısıra sağ dünya görüşünü benimseyenlerin Çukur'u "Adil/Adaletli bir mahalle" olarak görme veya okuma oranı \% 31 , sol görüşlülerin bu yönde kanaate salip olma oranı ise \% 21'dir. Hem sağ dünya görüşüne yakın duranlar hem de sol görüşlere yakın olanlar, hukuk içi adalet anlayışını imleyen, "Bir suç mahallesidir." yargısını karşıtı olan yargıdan daha yüksek oranda desteklemişlerdir. Bununla beraber, tabloya göre, kendisini dünya görüşü yelpazesinin sol tarafında konumlandıranların, sağ taraftakilere nispeten Çukur'un suç mahallesi kabul etme düzeyi \%11 daha yüksek; adil bir mahalle sayma oranı ise $\% 10$ daha düşüktür.

Bununla birlikte her iki şıkkı da seçen toplam izleyici katılımcıların, dünya görüşüne bakımından oranları incelendiğinde, "Bir suç mahallesidir" görüşünde olanların \%40’1 sağ görüşlüdür, \%53'ü de sol görüşe sahiptir. "Adil/Adaletli bir mahalledir" şıkkına yönelenlerin ise \%52'si sağ görüşlüyken, $\% 40$ düzeyinde sol görüş sahibi olanlardır..

Kendi içlerinde hem sağ görüşlülerin hem de sol görüşlülerin iki şıkkı birden tercih etme oranları ile her iki seçeneği işaretleyen toplam katılımcıların sağ görüşlü veya sol görüşlü olma oranlarına birlikte bakıldığında, sol görüşlülerin sağ görüşlülere kıyasla hukuk içi adalet arzusunu temsil eden "Bir suç mahallesidir" şıkkını daha fazla işaretledikleri görülmektedir.

Çukur'un adil/adaletli bir mahallesi mi yoksa bir suç mahallesi mi olduğu sorularına verilen cevapların bütün bağımsız değişkenlere göre tabloları ve oranları değerlendirildiğinde, toplumsal cinsiyet, eğitim, yaş, gelir durumu ve dünya görüşü değişkenlerine göre, değişik oranlarda farklılaşma olduğu sonucuna ulaşılmaktadır. Memur, öğrenci ve ev kadını meslek grupları incelendiğinde, Çukur'un suç mahallesi sayılma oranının yüksek olduğu, öğrencilerin eğitim durumunun çoğunlukla devam eden yüksek eğitime işaret ettiği ve ev hanımları grubunun da cinsiyet değerlendirmesine tâbi tutulacağından, bu iki grubun ağırlıklı olarak cevaplarının meslek kategorisi içinde değil, eğitim ve toplumsal cinsiyet değişkeni bağlamında değerlendirilmesi uygun görülmüştür. Söz konusu değişkenler bağlamında da, kadınların ve yüksek eğitimlilerin diğerlerine kıyasla daha fazla "Bir suç mahallesidir" yargısını destekledikleri dikkat çekmiştir. Bilhassa dünya görüşü ve toplumsal cinsiyet değişkenlerine ilişkin farklılaşmanın, diğer değişkenlerle kıyaslandığında, daha kuvvetli bir temeli olabileceği değerlendirilmektedir. Bunun nedeni, cinsiyet ve dünya görüşü değişkenine göre oluşturulan katılımcı gruplarının mevcutları birbirlerine yakındır, dolayısıyla dengeli bir dağılım olduğu söylenebilir. Yaş, eğitim ve gelir durumu değişkenlerine göre oluşturulan grupların niceliksel olarak yakın oldukları görülse de grupların kendi içlerindeki farklılaşmaları dikkate alınmalıdır. Sonuç olarak, gelir düzeyi, eğitim seviyesi ve yaş arttıkça Çukur'un bir suç mahallesi olduğu yönündeki yargıyı destekleme oranının arttığı görülmektedir. Bunun yanısıra, kadınların erkeklere, sol görüşlülerin de sağ görüşlülere kıyasla daha yüksek düzeyde "Bir suç mahallesidir" seçeneğinde yoğunlaştıkları sonucuna ulaşılmıştır. Bu konuda, medeni durum değişkenine göre Çukur'un nasıl bir mahalle olduğuna ilişkin yargılarda, yorumlamaya değer anlamlı bir farklılaşma olmadığı değerlendirilmektedir.

\section{Çukur Dizisi İzleyicilerinin Cezanın Amacına İlişkin Değerlendirmeleri}

Hukuk içi/hukuk dışı adalet bağlamı hesaba katılarak hazırlanan bir soru, izleyicilerin cezanın ne olduğuna dair fikirlerini açığa çıkaracak tarzda hazırlanmıştı. Ceza anlayışı da iki ayrı ucu temsil edecek şekilde kategorilendirilmişti. Buna göre birinci ceza anlayışı şöyle formüle edilmişti: Ceza, suçluya az zarar vererek, topluma olanaklı en yüksek caydırıcılık yararını temin etmelidir. Karşıt uç ise, cezanın suçu ve suçluyu yok etmeyi hedefleyerek acımasızca ve intikamcı bir motivasyonu taşımasıyd. Böylece hem vicdanen rahatlama hem de ibretlik bir durum 
yaratılmaktaydı. $\mathrm{Bu}$ bağlamda yorumlanabilecek şu soru izleyicilere yöneltilmişti: Kahraman Koçovalı'nın, sübyancı adamın kafasını ezmesi hakkında ne düşünüyorsunuz? Cevapları ise şu şekilde şıklandırılmıştır: 1) Haklıdır, cezasını vermiştir. 2) Onun yaptığı da suçtur, cezayı mahkemeler vermelidir. 3) Sapıklık cezasını Allah'tan bulmalıydı.

Soruda geçen öldürme eylemi, acımasız bir cezalandırma olduğundan cevaplardaki ilk şık bunu meşru, haklı ve uygun görenleri tespit eder. İkinci seçenek, formel bir hukuk ve adalet anlayışına sahip olmayı, yani cezanın resmi hukuk ya da yargı makamının vermesi gerektiğini savunanları belirler. Rahimov'un intikam ve kısas açısından ele aldığı (Rahimov, 2014: 20-27) dinsel bir adalet fikri ise üçüncü seçenekte formüle edilmiştir. İlk bölümlerde değinilen metafizik suçlar ve karşıllğında uygulanan dini yaptırımlar içerdiği iddia edilebilecek, "dinsel adalet", modern hukukun dışında olan adalet biçimidir. Buna karşlık, dinsel adalet, çağdaş ceza hukukunun kabul ettiği suçluya az zarar ve suçtan olabildiğince caydırma fikrine karşıt bir ceza anlayışı olan intikamcı adalet anlayışına yakındır (Rahimov, 2014). Bu sebeple, söz konusu üçüncü şık da gayri hukuki olma çerçevesinde yorumlanmıştır.

$\mathrm{Bu}$ sorunun cevaplarına bakıldığında, 69 kişinin "Haklıdır, cezasını vermiştir" ifadesini içeren birinci seçeneği, 4 kişinin üçüncü seçenek olan, "Sapıklık cezasını Allah'tan bulmalıdır." ifadesini, geri kalan 134 izleyicininse "Onun yaptı̆̆ı da suçtur, cezayı mahkemeler vermelidir" şıkkını benimsedikleri gözükmektedir. Bu sorunun yanıtları cezanın amacının intikam ve suçluya zarar verme olduğunu düşüncesine sahip olma durumunu temsil eden birinci ve üçüncü seçeneklere yönelen izleyicilerin, ceza hakkında modern hukukun yaklaşımını ifade eden ikinci seçenekten yana tutum takınanlara kıyasla belirgin düzeyde düşük sayıda olduğunu göstermiştir.

$\mathrm{Bu}$ sorudaki yanıtların cinsiyet, yaş, eğitim-gelir ve dünya görüşü değişkenleri bakımından dağılımları incelendiğinde, nispeten erkeklerin kadınlara göre daha yüksek oranda intikamcı adalet anlayışını imleyen birinci seçeneği işaretledikleri görülmektedir. Bir diğer bulgu da, yaş ilerledikçe ve eğitim yükseldikçe bu seçeneği işaretleme oranının düşmesidir. Meslek değişkeni hesaba katıldığında, ev hanımlarının \% 80'inin, öğrencilerin \% 64'ünün, memurların \% 83'ünün ikinci seçeneği işaretlediği tespit edilmiştir. Sonuç olarak, söz konusu meslek gruplarının intikamcı adalet anlayışını temsil eden birinci şıkka yönelme oranları düşüktür. Önceki sorularda da incelendiği üzere Çukur dizisi izleyici katılımcılarından öğrencilerin \%81'ni yüksek eğitim düzeyinde eğitim görenler oluşturmaktadır. $\mathrm{Bu}$ anlamda, öğrencilerin yüksek oranda ikinci seçeneği, düşük oranda ilk şıkk1 tercih etmeleri, eğitim seviyelerine bağlanabilir. Buna ek olarak, ev kadınlarının da yüksek oranda ikinci, bundan daha az oranda birinci şıkkı işaretlemeleri ile kadınların erkeklere kıyasla daha yüksek oranda ikinci, daha düşük oranda ilk şıkkı benimsemeleri bir arada değerlendirilebilir. Meslek gruplarından memurların da ilk şıkkı işaretleme oranları düşüktür. Medeni durum değişkeni düşünüldüğünde, bekârların, evlilere göre daha yüksek oranda ilk şıkkı seçtikleri görülmüştür. Gelir durumu değişkeni hesaba katıldığında, gelir grupları arasında belirgin bir farklılaşma olmamakla birlikte, ilk şıkkı işaretlenme oranının düşük gelirlilerde, çok düşük gelirlilere kıyasla daha az, normal sınır ve üstünde gelire sahip olanlarda ise düşük gelirlilere göre daha yüksek olduğu sonucuna ulaşılmıştır. Bununla beraber, çok düşük gelirlilerle öteki gruplar arasındaki farka bakıldığında, çok düşük gelirlilerin cezanın ıslah edici veya suçtan caydırıcı kaygılarla verilmesi gerektiği kanaatinden ziyade, intikamcı ceza anlayışına daha yakın oldukları söylenebilir. Dünya görüşü değişkeni düşünüldügünde ise, sol görüşlüler, sağ görüşlülere kıyasla çok daha düşük oranda ilk seçeneği, yüksek oranda ikinci şıkkı tercih etmiştir. Sonuç olarak, gerek Cinsiyet, yaş, eğitim, meslek gerekse dünya görüşü değişkenleri hesaba katıldığında, intikamcı adalet anlayışını ya da bunun zıttı olarak tanımladığımız suçluyu rehabilite etmek, topluma kazandırmak ve toplumun fertlerini suçtan caydırma amaçlı adalet anlayışını temsil etmesi için formüle edilen yorumlama seçenekleri arasında anlamlı farklılaşmalar olduğu açıktır. 


\section{Çukur Dizisi İzleyicilerinin Suçun Sorumluluğu Hakkındaki Değerlendirmeleri}

"Çukur'da yaşayanların karıştıkları ve işledikleri suçlar hakkında ne düşünüyorsunuz?" sorusuyla, izleyicilerin suçun temelini oluşturan güdülerin ve suça dair sorumluluğun kişisel mi toplumsal mı olduğu konusundaki fikri açığa çıkarılmak istenmiştir. Birinci seçenek suçun ve o suça dair sorumluluğun bireysel olduğu yönünde, ikincisi ise toplumsal olduğu yönünde yorumlanacak şekilde hazırlanmıştır. Bu soruya ilişkin yanıtların, toplumsal cinsiyet, yaş, medeni durum, eğitim düzeyi, meslek, gelir durumu ve dünya görüşü değişkenlerine göre dağ 11 lım1, tablolarda gösterilmiştir:

Tablo 21: Cinsiyet - Çukur Halkı Neden Suç İşler?

Suç düzenine ayak İçinde doğdukları koşullardan uydurmayı kendileri dolayı suçla yaşamaya seçmiştir. mecbur kalmışlardır.

\begin{tabular}{|c|c|c|c|c|c|}
\hline & & & seçmiştir. & mecbur kalmışlardır. & Toplam \\
\hline \multirow{8}{*}{ Cinsiyet } & \multirow[t]{4}{*}{ Erkek } & Say1 & 44 & 58 & 102 \\
\hline & & $\%$ Cinsiyet içinde & $43 \%$ & $57 \%$ & $100 \%$ \\
\hline & & $\% \mathrm{Bu}$ soru içinde & $60 \%$ & $44 \%$ & $49 \%$ \\
\hline & & $\%$ Toplam içinde & $21 \%$ & $28 \%$ & $49 \%$ \\
\hline & \multirow[t]{4}{*}{ Kadın } & Sayı & 30 & 75 & 105 \\
\hline & & $\%$ Cinsiyet içinde & $29 \%$ & $71 \%$ & $100 \%$ \\
\hline & & $\%$ Bu soru içinde & $41 \%$ & $56 \%$ & $51 \%$ \\
\hline & & $\%$ Toplam içinde & $15 \%$ & $36 \%$ & $51 \%$ \\
\hline \multirow[t]{3}{*}{ Toplam } & & Say1 & 74 & 133 & 207 \\
\hline & & $\%$ Bu soru içinde & $100 \%$ & $100 \%$ & $100 \%$ \\
\hline & & $\%$ Toplam içinde & $36 \%$ & $64 \%$ & $100 \%$ \\
\hline
\end{tabular}

Bu soruya \%43 oranında erkek ve \%27 oranında kadın katılımeı "Suç düzenine ayak uydurmayı kendileri seçmiştir" şıkkını, böylece suçun altında yer alan güdülerin ve sorumluluğunun kişisel olduğu şeklinde yorumlanabilecek birinci opsiyona yönelmiştir Suçun temelindeki ana faktörün ve suçta mesuliyetin bireysel değil toplumsal olduğu sonucunun çıkarılabileceği, "içine doğdukları koşullardan dolayı suçla yaşamaya mecbur kalmışlardır." şıkkını tercih etme oranı ise erkeklerde $\% 57$, kadınlarda ise $\% 71$ 'dir. Bu soruda erkekler, kadınlara oranla daha yüksek düzeyde, suçu bireysel görmeye ilişkin seçeneği işaretlemişlerdir.

Suçun bireysel yönünü vurgulayan birinci seçeneği işaretleyen 74 katılımcının cinsiyet bakımından oranlarına bakıldığında ise, \%60'ının erkek, \% 41'inin kadın olduğu görünmektedir. Suça ilişkin sorumluluğun bireyselin ötesinde toplumsal boyutlarını odağına alan ikinci şıkk1 işaretleyen toplam 133 izler kitle katılımcısının ise \% 44'ü erkek, \% 56'sı kadın olmuştur. Cinsiyete göre gruplandıklarında, her bir grup katılımcının her iki seçeneği işaretleme oranları ve her iki seçeneği işaretleyen toplam katılımcının cinsiyete göre dağılımları incelendiğinde, kadınların erkeklere oranla daha fazla, suçun toplumsal taraflarına öne çıkaran kanaate yöneldikleri görülmüştür. $\mathrm{Bu}$ soruya verilen cevaplarda yaşa göre birinci ve ikinci şıkkı işaretleme oranlarında düzenli yükseliş veya düşüş göze çarpmamıştır. Katılımcıların cevapları medeni hal değişkeni bakımından değerlendirildiğinde ise, evli katılımcıların \%33, bekâr katılımcıların ise \%38 oranında birinci seçeneği işaretlediği görülmektedir. Katılımcıların 8'ini oluşturan, boşanmış/dul katılımcı ise \%25 oranında (sadece iki kişi) aynı şıkkı işaretlemişlerdir. Dul/boşanmış izleyici katılımcıların sayısının çok az olması, evli ve bekâr katılımcıların ise seçenekleri işaretlemek bakımından aralarında anlamlı bir fark olmaması, nedeniyle bu soruda medeni durum değişkenine göre yorumlanmayı gerektiren bir ayrım görülmemiştir.

Eğitim düzeyi değişkenine göre yapılan değerlendirmede ise, düşük eğitim düzeyindeki katılımcıların \% 25'inin, orta eğitim düzeyindeki katılımcıların \% 43,2'sinin, yüksek eğitim düzeyindeki katılımcıların ise \% 35,1'inin suçun bireysel boyutunun altını çizen ilk şıkk1 işaretledikleri sonucuna ulaşılmıştır. Suçun toplumsal boyutunu imleyen ikinci seçeneği 
işaretleyenlerin ise, $\% 75$ 'inin düşük eğitim düzeyinde, \% 57'sinin orta eğitim düzeyinde, $\% 65$ 'inin ise yüksek eğitim düzeyinde olduğu görülmüştür. Katılımcıların eğitim düzeyinde düşükten yükseğe doğru gidildikçe, bu soruya verdikleri yanıtlarda düzenli bir yükselişin söz konusu olmadığ1 görülmektedir. Ancak, düşük eğitim düzeyindeki katılımcıların, diğer eğitim düzeylerindeki katılımcılarla karşılaştırıldığında, daha yüksek oranda, suça dair sorumluluğun toplumsal olduğuna yönelik olan ikinci seçeneği işaretledikleri dikkat çekmektedir.

Toplamda sadece 8 kişi olsalar da esnafların \%63'ünün, ev hanımlarının \%60'ının, işçilerin \%85'inin, öğrencilerin \%55'inin, memurların \%73'ünün ve işsizlerin ise \%71'inin suçun toplumsallığını vurgulayan ikinci seçeneği işaretledikleri görülmüştür. Kadın katılımcıların geneli değerlendirildiğinde \%70'in üzerinde suçun toplumsal yönüne ilişkin ikinci şıkkı işaretledikleri, ev hanımı olan kadınlar düşünüldügünde ise oranın \%60' a düştüğü tespit edilmiş olsa da, bu soru için göreli olarak yüksek oranda bu şıkkı işaretleyen meslek gruplarından birinin ev hanımları olduğu söylenebilir.

Gelir seviyesi bakımından yapılan değerlendirme, çok düşük gelirlilerin \% 29'unun, düşük gelirlilerin \%38'inin, normal düzey ve üzerinde gelire sahip olanların ise \% 34'ünün suçun bireysel boyutunu vurgulayan ilk şıkk1 işaretlediklerini ortaya koymuştur. Suçun toplumsal boyutunu vurgulayan ikinci şıkka yönelme oranı ele alındığında ise, oranın çok düşük gelirlilerde \%71, düşük gelirlilerde $\% 62$, normal sınır ve bunun üstünde gelirlilerde \% 66 olduğu görülmüştür. Anlaşılacağı üzere, soruların bazılarında gelir seviyesine göre düzenli düşüş veya yükseliş gösteren tablo, bu soruda sorgulanan konuya dair gelir durumuna göre tutarlı bir farklılaşma göstermemiştir. Bununla birlikte, çok düşük gelir seviyesindeki katılımcıların bu soruda diğer gelir seviyesindeki katılımcılara kıyasla daha yüksek oranda (\%71) toplumsal sorumluluğu vurgulayan seçeneği işaretledikleri dikkat çekmektedir.

Tablo 22: Dünya Görüşü - Çukur Halkı Neden Suç İşler?

\begin{tabular}{|c|c|c|}
\hline $\begin{array}{l}\text { Suç düzenine } \\
\text { ayak uydurmayı } \\
\text { kendileri } \\
\text { seçmiștir }\end{array}$ & $\begin{array}{l}\text { İçinde doğdukları } \\
\text { koşullardan dolayı } \\
\text { suçla yaşamaya } \\
\text { mecbur kalmışlardır. }\end{array}$ & Toplam \\
\hline 37 & 51 & 88 \\
\hline $42 \%$ & $58 \%$ & $100 \%$ \\
\hline $50 \%$ & $38 \%$ & $43 \%$ \\
\hline $18 \%$ & $25 \%$ & $43 \%$ \\
\hline 29 & 70 & 99 \\
\hline $29 \%$ & $71 \%$ & $100 \%$ \\
\hline $39 \%$ & $53 \%$ & $48 \%$ \\
\hline $14 \%$ & $34 \%$ & $48 \%$ \\
\hline 8 & 12 & 20 \\
\hline $40 \%$ & $60 \%$ & $100 \%$ \\
\hline $11 \%$ & $9 \%$ & $10 \%$ \\
\hline $4 \%$ & $6 \%$ & $10 \%$ \\
\hline 74 & 133 & 207 \\
\hline $100 \%$ & $100,0 \%$ & $100 \%$ \\
\hline $36 \%$ & $64 \%$ & $100 \%$ \\
\hline
\end{tabular}

Suçun temelleri ve suça dair sorumluluğunun bireysel mi yoksa bireyin ötesinde toplumsal koşullarla mı ilgili olduğuna ilişkin sorgulama ekseni, esasen Dostoyevski'nin Suç ve Ceza romanı üzerine, suçun sorumluluğunun kaynağını odağına alan, sağ ve sol bakış açılarıyla yapılan çeşitli yorumlamalardan ilham alınarak kurulmuştu. Buradan hareketle, dünya görüşü değiş̧keninin, suçun sorumluluğunu irdeleyen sorularda en önemli değerlendirme ölçütü olduğu söylenebilir. Bu ölçüt temel alındığında tabloda görüldüğü üzere, sağ görüşlüler kendi içinde $\% 42$ oranında, sol görüşlüler 
ise \%29 oranında suçun bireysel yönüne önem atfedenlere ilişkin ilk şıkk işaretlemişlerdir. Suçun toplumsal boyutlarını vurgulayan ikinci şıkka yoğunlaşma düzeyi sağ görüşe sahip olanlarda $\% 58$, sol görüşlülerde ise $\% 71$ 'dir.

$\mathrm{Bu}$ sorunun yanttlarındaki genel durum değerlendirildiğinde, erkeklerin kadınlarla karşılaştırıldıklarında daha fazla oranda, suçu bireysel kabul edenlere yönelik şıkkı işaretledikleri tespit edilmiştir. Suça temel teşkil eden unsurun ve suçun sorumluluğunun bireyselin ötesinde toplumsallı̆̆ına vurgu yapan seçeneği işaretleme oranı ise erkeklerde $\% 57$, kadınlarda ise $\% 71$ 'dir. Kadınların daha yüksek oranda toplumsal sorumluluk anlayışına yatkın oldukları görülmektedir. Yaş ve medeni durum değişkenleri hesaba katıldığında ise anlamlı bir farklılık görülmemiștir. Eğitim düzeyi yükseldikçe suça ilişkin toplumsal veya bireysel sorumluluk anlayışına dair seçenekleri işaretleme oranında düzenli bir artış ya da düşüş olmamıştır. Buna rağmen, düşük eğitim düzeyindeki katılımcıların, ötekilere kıyasla biraz daha fazla oranda suçta toplumsal sorumluluğun önemine işaret eden seçeneği işaretledikleri görülmüştür. Toplamda 8 kişi olan esnafların \% 63'ünün, ev hanımlarının \%60'ının, işçilerin \% 85'inin, öğrencilerin \%55'inin, memurların \% 73'ünün, işsizlerin ise \% 71'inin suçun toplumsal yönünü vurgulayan ikinci seçeneği işaretledikleri de çıkan sonuçlar arasındadır. Gelir seviyesi ile herhangi bir şıkkı tercih etme oranları arasında düzenli bir bağlantı görülmemiş olsa da, çok düşük gelir seviyesindeki izleyici katılımcıların diğerlerine göre biraz daha yüksek düzeyde suçun toplumsal sorumluluğunu imleyen seçeneği işaretlemiş olmaları ilgi çekicidir. Dünya görüşü değişkeni hesaba katıldığında ise, sağ görüşe sahip olanların \% 58'inin, sol görüşlülerin ise \%71'inin suçun sorumluluğunun toplumsal boyutlarını öne çıkaran ikinci şıkı1 işaretledikleri görülmüştür. Tüm sonuçların 1şında, yalnızca cinsiyet ve dünya görüşü değişkeni söz konusu olduğunda anlamlı bir farklılaşmadan söz edilebilmektedir. Bu doğrultuda, kadınların erkeklere, sol görüşlere yakın olanların ise sağ görüşlülere göre daha yüksek oranda suçta mesuliyetin toplumsal olduğunu düşündükleri sonucuna ulaşılmıştır.

\section{İzleyici ve Adalet: Hakim ve Muhalif Okumalar Bağlamında Bir Değerlendirme}

Katılımcıların, izleyicisi oldukları Çukur dizisine dair olay ve durumlar hakkında şu ikilikler etrafında bir konum almaları istenmişti: adalet hukuk içi mi hukuk dışı sağlanmalıdır? Cezanın amacı bakımından: öç alma/acı verme mi yoksa rehabilitasyon mu? Sorumluluk bakımından: Suç bireysel mi, toplumsal mi?

Verilen yanıtlara göre genel duruma bakıldığında, belli değişkenler bağlamında bazı grupların diğerlerine göre daha yüksek oranda hukuk içi adalet arzusunu, suçluyu rehabilite etmeye yönelik ceza isteğini ve suçun toplumsal yönünü işaret eden seçenekleri işaretlediği görüldü. $\mathrm{Bu}$ ayrım eksenlerinde çeşitli demografik değişkenlere göre daha yüksek oranda tercih edilen seçeneklere bakarak, dizi izleme pratiği üzerinden adalet anlayışının nasıl ve hangi etkenlere göre farklılaştı̆̆ını görebiliriz.

Çukur izleyicilerine yönelik hazırlanan, Koçova Mahallesi (Çukur) hakkında ne düşündüklerine dair soruya verilen ve ilgili bölümdeki tablolarda detaylıca gösterilen yanıtların dağılımına bakıldığında, bazı demografik değişkenler hukuk içi adalet, ıslah edici ceza ve suçun toplumsallığı yönünde yanıtlarla birlikte daha yoğun olarak görüldü. Çukur dizi metninde, suç davranışları kendi içinde belli bir adalet anlatısı ile örülerek kodlanmıştır. Bu dizi metninde hakim anlam, hukuk dışı adaletin uygun olduğuna yöneliktir. Hukuk dişı yöntemlerle adaleti sağlamaya yönelik bir anlatı içinden, hukuk dışı adalet anlayışı meşru olarak sunulmaktadır. Bu nedenle bu dizi metni karşısında hukuk içi adalet arzusunu işaret eden seçeneklerle daha yoğun oranda birlikte görülen demografik özelliklerin, aynı zamanda bu metin karşısında muhalif bir konum almak konusunda önemli etken olduğu söylenebilir. Hukuk içi adaleti daha yüksek oranda talep eden ve böylelikle bu konuda nispeten daha yüksek oranda muhalif okuma yapanlar, eğitim düzeyi daha yüksek olanlar, aylık ortalama gelir düzeyi daha yüksek olanlar, kadınlar ve sol görüşlülerdir. Meslek olarak memurlar, öğrenciler ve ev kadınları da öbür meslek gruplarına kıyasla daha fazla oranda 
adaletin formel hukuk içinde sağlanması gerektiğine işaret eden seçeneği işaretleyerek, metin karşısında muhalif bir konum almışlardır.

İdris Koçovalı karakterinin büyük oğlu Kahraman Koçovalı'nın çocuk istismarcısı bir adamın kafasını taşla ezerek öldürdüğü sahne ile ilgili düşünceleri toplamaya yönelik hazırlanan soru ve Çukur mahallesinin sonunun ne olması gerektiğine yönelik hazırlanan soruya verilen yanıtlarda da benzer şekilde, eğitim ve gelir düzeyi yüksek olanlar ile kadınlar ve sol görüşlüler hukuk içi bir adalet anlayışına yakın olan seçenekleri nispeten daha yüksek oranda işaretlediler. Bu iki soruda bunlara ek olarak, evliler de bekârlara göre daha yüksek düzeyde hukuk içi adalete işaret eden seçeneği tercih ederek, aynı zamanda dizi metni karşısında muhalif bir konum aldılar.

Çukur dizisinde "Kahraman Koçovalı'nın, sübyancı adamın kafasını taşla ezerek öldürmesi hakkında ne düşünüyorsunuz?" sorusu, hukuk içi ve yahut hukuk dışı adalet anlayışını ölçmeye yönelik olarak hazırlanmıştı. Bununla birlikte, öç almaya yönelik acımasız bir ceza anlayışı veya 1slah edici bir ceza anlayışı yönünde de değerlendirilmiştir. Bu soruda da eğitim düzeyi yüksek olanlar, yüksek gelir düzeyine sahip olanlar, kadınlar ve dünya görüşü sola yakın olanlar, diğerlerine kıyasla daha yüksek oranda ıslah edici cezadan yana tavır sergilediler. Ayrıca evli olanlar bekârlara kıyasla, memur, öğrenci ve ev hanımı olanlar da diğer mesleklerden katılımcılara kıyasla daha yüksek oranda aynı yönde tavır göstermişlerdir. Dizide çocuk istismarcısını öldürme eylemi de haklı olarak gösterilmiş, istismarcının acımasız şekilde öldürülmesi, adaletin yerini bulması şeklinde sunulmuştur. Metindeki hakim kod bu yönde olduğundan, sözü edilen demografik özelliklere sahip olanlar yine bu metin karşısında muhalif konum almışlardır.

Suçun sorumluluğunun bireysel veya toplumsal olduğuna ilişkin düşünceleri almaya yönelik hazırlanan sorularda ise yoğun olarak, suçun toplumsal yönüne işaret eden seçenekler işaretlenmiştir. Vartolu Saadettin karakterinin neden suç işlediğine dair soruda katılımcılar çok yüksek oranda, öyle ki herhangi bir demografik değişkene göre farklılık göstermeksizin, toplumsal nedenlerden dolay1 suç işleyen bir kişi haline geldiğini düşünmüştür. Bu konuda izleyicinin tavrı, aynı zamanda metinde kodlanan anlamla uyumludur. Dizi metninde Vartolu Saadettin karakterini suça iten nedenler ve yaşam öyküsü dramatik şekilde işlenmiş ve çocukluğundan beri maruz kaldığı kötü muamele ve koşulların sonucu olarak suç işlediği yönünde bir kodlama yapılmıştır. Bu bağlamda izleyicinin tavrı, aynı zamanda metin karşısında yeğlenen okumaya karşılık gelir.

Çukur halkının neden suçla iç içe yaşadığına dair soruda ise eğitim düzeyi hiç fark etmeksizin katılımcılar yoğun olarak yine mahallelinin suç işlemesinin dışsal ve toplumsal boyutlarını gördüler. Tüm demografik özelliklere göre katılımcılar daha yüksek nispette suçun toplumsal yönlerini görmekle, aynı zamanda yine metin karşısında egemen okuma pratiği gerçekleştirmiş oldular. Dizi metninde Çukur'un kendi içinde tutarlı ve kendi suçları olmayan nedenlerden dolayı suçla iç içe olan kişilerin yaşadığı vurgusu hakimdir. Böylece bu soruda da hakim okuma pratiği genel olarak daha yoğun olmuştur. Ancak yine de düşük eğitimliler yüksek eğitimlilere, çok düşük gelir seviyesindekiler de daha yüksek gelir düzeyine sahip olanlara kıyasla suçun toplumsal boyutlarını işaret eden seçeneği daha yüksek oranda işaretlemişlerdir. Yine kadınlar erkeklere, sol görüşlüler ise dünya görüşü sağa yakın olanlara kıyasla daha fazla suçun toplumsal yönünün altını çizen şıkı tercih ederek, metinde kodlanan hakim anlamlar yönünde okuma yapmışlardır.

\section{Genel Değerlendirme ve Tartışma}

İzleyiciler, sosyoekonomik koşulları ve dünya görüşleri çerçevesinde farklı şekillerde, kimi soruda metinde kodlanan hakim (yeğlenen) anlamlar yönünde, kimi soruda bu hakim anlamlara karşıt yönde, bazı sorularda ise metindeki çift anlamlılığa bağlı olarak karmaşık ve birçok etkene dayanan, kendi toplumsal konumları ve bağlamlarıyla uyumlu, okumalar yapmışlardır. Bu durum, aktif izleyici yaklaşımlarının varsaydığı izleyici anlayışına uyan somut bir veri setini önümüze koymuştur. Ancak bu veri seti, izleyicinin okuma çerçevesinin oldukça sınırlandırılmış olduğuna savunan bir 
uçtan, bu çerçevenin hiçbir şekilde sınırlandırılmamış olduğunu kabul eden diğer uca kadar uzanan düşünsel sarkaç içinde de yorumlanabilir. Bu bakımdan, izleyicinin hangi uca daha yakın konumlandığını tartışabiliriz. Toplam katılımcıların verdikleri yanıtlar demografik verilere göre farklılıkları dikkate almaksızın ve tüm demografik değişkenlere göre farklılaşan durumlar dikkate alınarak değerlendirildiğinde bazı durumlarda hakim okumalar, bazı durumlarda da muhalif okumalar yapıldığ 1 görülmüştür. Bu nedenle, bu veri seti içinden metnin ve kodlama sürecinin ağırlığını ön plana çıkaracak veriler kullanılarak izleyicinin anlamlarının belirlenmişliğine vurgu yapılabileceği gibi, izleyicinin metin karşısındaki potansiyelini ön plana çıkaracak veriler kullanılarak izleyicinin sınırsız yaratıcılığına da dikkat çekilebilir. Ancak egemen ve muhalif okumalar, farklı soruların dizi içeriğindeki karşılığı olan konulara ve durumlara göre öylesine farklılık göstermiştir ki Hall'ün kodlama ve kodaçımı kavramsallaştırmasının ardından yapılan erken dönem çalışmalardaki gibi kodlama sürecinin ve dolayısıyla metnin anlamı sınırlayıcı kuvvetini ön plana çıkarmak mümkün değildir. İzleyicinin aktif tavrı bu tür bir değerlendirmeye imkân bırakmamıştır. Ancak, Morley'in (2005) eleştirdiği ve izleyiciyi adeta toplumsal bağlamları ve koşullarından soyutlamaya varacak kadar aktif bir izleyici öngören yaklaşımların varsayımına uygun bir izleyici profili de söz konusu değildir. Elimizdeki veri setine bakarak sürekli ve tüm koşullarda mutlak şekilde, istediği yönde anlamlandırabilen bir tür izleyiciyi varsaymak da mümkün değildir. Etkin bir izleyici olarak nitelendirilebilecek ölçüde, metinde kodlanan anlamlardan bağımsız düşünebilen, onlara karşı eleştirel bir konum alabilen, ancak yine de sınırsız bir özgürlük alanında tamamen aktif ve metinde kodlanmış olan anlamlardan tamamen bağımsız konum alması mümkün olmayan bir izleyici profili ile karşı karşıya olduğumuz söylenebilir. Bu çalışmadaki "etkin izleyici", oldukça sınırlandırılmış anlam çerçeveleri içinde hareket eden izleyici varsayımı ile sınırsız bir özgürlük alanında istediği şekilde anlam üretebilen izleyici varsayımı arasındaki düşünsel sarkacın iki uçtan biri lehine konumlanmadığı, ortalarda sallandığ bir konumda değerlendirilebilir.

\section{Sonuç}

$\mathrm{Bu}$ izleyici araştırmasında, Çukur dizisi izleyicilerinin adalet anlayışları incelenmiştir. Bu adalet anlayışı incelemesi şu kategorik ayrımlar etrafında yapılmaya çalışılmışıı: a) hukuk içi hukuk dışı olma b) cezanın amacı bakımından öç alma - kazanma (rehabilite etme) c) sorumluluk bakımından bireysel - toplumsal. İzleyicilerin, anlatı karşısında aldıkları özne konumunun ne olduğu yani Hall'ün ana hatlarını geliştirdiği okuma biçimleri kavramsallaştırması bağlamında (hakim, muhalif, müzakereci) nerede durduğuna dair değerlendirme yapıldı. İzleyicinin ne kadar aktif olduğu tartışıldı. İzleyicinin belirlenmiş bir okur olma ile hiçbir belirleyici olmaksızın özgür okur olma arasındaki salınımı analiz edildi. Yorumlamanın metnin gömülü anlamları etrafında çeşitlenmesinin, izleyici özne konumlarının karmaşıklığını ve çok katmanlılı̆̆ını ortaya koyduğu söylenebilir. David Morley'in "sarkaç" metaforu ile açıkladığı, yaklaşım farklılıklarındaki iki uçtan birine yakınlaşma haliyle değerlendirilemeyecek bir izleyicilik durumu olduğu görülmüştür. Bu yüzden, metafor içinde düşünmeye devam ederek söylemek gerekirse, aslında ortalarda hafif salınan bir sarkaç gibi, bazen metinde kodlanan anlamlar lehine okuma yapmaya, bazen de farklı değişkenlere göre metinde kodlanandan epey uzak okumalar yapmaya yönelen bir izleyicilikten söz edebiliriz.

Adaletin göreliliğini sorgulamak niyetiyle oluşturulan üç araştırma ekseni bağlamında, adaletin görelilik ölçütleri olarak Anıl Çeçen'in tanımladığı sınıf, yer, zaman ve görüş unsurları çerçevesinde, izleyicilerin demografik niteliklerine göre, hangi adalet anlayışına benimsemiş oldukları sorgulandı. Sorgulamada sınıf unsuru, Pierre Bourdieu'nün (2017) maddi ve sembolik (kültürel) olanı birlikte içeren toplumsal tabakalaşma teorisine göre ele alındı. Genel sonuçlara göre, adaletin göreliliği konusunda sahip olunan ekonomik ve kültürel sermayenin yüksekliği, yani alt sınıfa değil de orta sınıfa yakın olmak ve dünya görüşünün sola yakın olması, çağdaş hukukun mantığ 1 içinde biçimlenen adalet anlayışının kimi unsurlarını büyük oranda kabul etme durumuyla birlikte görüldü. Ayrıca, toplumsal cinsiyet konumunun da hem medya karşısında izleyici konumu üzerinde, hem de adalete yaklaşım biçimi üzerinde önemli olduğu söylenebilir. Sınıfsal durum, siyasi 
fikir ya da dünya görüşü ve toplumsal cinsiyet, adaletin göreliliği meselesinde önemli değişkenler oldu. Ancak toplumsal cinsiyete bağlı özne konumları üzerinden işleyen izleyici okumalarını çözümlemek ve bunun üzerine adalet anlayışları hakkında iddialar geliştirmek ise bu araştırma kapsamında pek mümkün olamadı. Araştırmanın sınırları dışında kalan bu değerlendirme, feminist izleyici araştırmaları literatürü içinden, dizi izleyicileri üzerine yapılacak başka araştırmalar ile ortaya konabilir.

Suçun nedenleri ve buna bağlı olarak suçun sorumluluğunun, bireysel etkenlerde mi yoksa bireyin dışındaki kimi toplumsal faktörlerde mi olduğuna ilişkin görüşler üzerine yapılan değerlendirmede, bu konuda dünya görüşü ve toplumsal cinsiyet değişkenleri, yaklaşımları farklılaştıran görelilik ölçütleri oldu. Kısacası, sınıfsal ve cinsiyete bağlı konumlar ile dünya görüşünün, farklı izleyici konumları içinden farklı okumalar yapmak ve adalet konusundaki yaklaşımların göreliliğinde ayrımları kuran etkenler olarak ortaya çıktığı söylenebilir. Ancak belli durumlarda medya kültürü, izleyici konumunu, medya metnini anlamlandırma çerçevelerini ve adalete dair bazı düşünceleri yönlendirmek bakımından, sınıf, dünya görüşü ve cinsiyet etkenlerini devre dışı bırakacak sonuçlara yol açtı. Araştırma sonunda maddi ve sembolik boyutlarıyla özne konumlarının, medya metnini anlamlandırma ve adalet anlayışını biçimlendirdiği, ayrıca daha genel bir medya (TV) kültürünün özgün bir izleme ve yorumlama tarzını yapılandırdığı iddia edilebilir.

\section{Kaynakça}

Akal, C. B. (2014). Hukuk Öğrencisi Raskolnikov Suç ve Ceza'yı Okumaya Mahkûm Edildi. Birikim (298), 91-96.

Akçay Gültekin, Z. (2011). Türkiye'de Bir Dramedi Türü. S. C. Yağcı Aksel (Ed.), Beyaz Camın Yerlileri (s. 53-84). Umuttepe.

Atay, T. (2017). Referandum dizileri. Cumhuriyet Gazetesi. https://www.cumhuriyet.com.tr/yazarlar/tayfun-atay/referandum-dizileri-713808

Aziz, A. (2017). Sosyal Bilimlerde Araştırma Yöntemleri ve Teknikleri. Nobel.

Beccaria, C. (2018). Suçlar ve Cezalar Hakkında. (S. Selçuk, Çev.). İmge.

Bourdieu, P. (2017). Ayrım. (D. F. Berkkurt, Çev.). Heretik.

Çeçen, A. (1993). Adalet Kavramı. Gündoğan.

Çelenk, S. (2005). Televizyon, Temsil, Kültür: 90’lı Yıllarda Sosyokültürel İklim ve Televizyon İ̧̧erikleri. Ütopya.

Çelenk, S. (2010). Aşk-1 Memnu'dan Aşkı Memnu’ya Yerli Dizi Serüvenimiz. Birikim (256/257), $18-27$.

Durkheim, E. (2006). Toplumsal İşbölümü. Cem.

Hall, E. T. (1959). The Silent Language. Fawcett Publications.

Hall, S. (2005). Kodlama, Kodaçımlama. (Ş. Yavuz, Çev.). Ş. Yavuz (Ed.), Medya ve İzleyici Bitmeyen Tartışma (s. 85-99). Vadi.

Jaspers, K. (2015). Suçluluk Sorunu. (A. E. Zeybekoğlu, Çev.). İthaki.

Jensen, K. B. (2002). A Handbook of Media and Communication Research. Routledge.

Karabağ Sarı, Ç. (2013). 12 Eylül Filmleri ve Üniversite Gençliği: Politik Söylemler Bağlamında 12 Eylül Filmlerinin Alımlanması.sinecine. Sinema Araştırmaları Dergisi/Journal of Film Studies, 4 (2), 9-39. 
İlhan, V. (2010). Medya ve Gençlik: 15-24 Yaş Arası Gençlerin Televizyon Dizilerini İzleme Pratiklerindeki Dönüşüm. (Yayımlanmamış Doktora Tezi). Erciyes Üniversitesi.

Lefebvre, H. (2007). Modern Dünyada Gündelik Hayat. (I. Gürbüz, Çev.). Metis.

Lewis, J. (2010). İzlerkitle. (E. Mutlu, Çev.). E. Mutlu (Ed.), Kitle İletişim Kuramları (s. 344-358). Ütopya.

Liebes, T., \& Livingstone, S. (1998). European soap operas: The diversification of a genre. European Journal of Communication. https://doi.org/10.1177/0267323198013002001

Mattelart, A., \& Mattelart, M. (1998). İletişim Kuramları Tarihi. (M. Zıllığlu, Çev.). İletişim.

Morley, D. (2005). Etkin İzleyici Kuramı: Sarkaçlar ve Tuzaklar. (Y. Yavuz, Çev.). Ş. Yavuz (Ed.), Medya ve İzleyici Bitmeyen Tartısma (s. 99-104). Vadi.

Morson, G. S. (2016). The Disease of Theory: Crime and Punishment at 150. New Criterion, 34(9), 4-10.

Mutlu, E. (1991). Televizyonu Anlamak. Gündoğan.

Özsoy, A. (2011). Televizyon ve İzleyici: Türkiye'de Dönüşen Televizyon Kültürü ve İzleyici. Ütopya.

Öztürk, M., \& Atik, A. (2016). Ulusal Pazardan Küresel Pazarlara Uzanan Süreçte Türk Dizilerinin Gelişimi. Maltepe Üniversitesi İletişim Fakültesi Dergisi, 3(2), 66-82. https://dergipark.org.tr/tr/download/article-file/304424

Punch, K. F. (2003). Survey Research: The Basics. SAGE.

Rahimov, İ. (2014). Suç ve Ceza. (T. Veli, Çev.). Türkiye Barolar Birliği.

Roscoe, J., Harriette, M., \& Gleeson, K. (2005). Kabuledilmiş "Etkin", "Sosyal", ve "Eleştirel" Terimlerinin Yeniden Ele Alınması. (Y. Yavuz, Çev.). Ş. Yavuz (Ed.), Medya ve İzleyici Bitmeyen Tartışma (s. 45-75). Vadi.

RTÜK. (2018). Televizyon İzleme Eğilimleri Araştırması 2018. RTÜK Yayınları.

Sönmez, M. (2010). Medya, Kültür, Para ve İstanbul İktidart. Yordam Kitap.

Tanrı̈ver, H. U. (2012). Türkiye'de Televizyon Yayıncıll̆ğ 2011. İstanbul Ticaret Odası.

Tekelioğlu, O. (2017). Televizyon Halleri: Dizi Dizi Televizyon. Habitus.

Ülken, H. Z. (2016). Ahlak. Doğu Bat1.

Yağcı Aksel, S. C. (2011). Yerli Dizi Serüveninde 37. Sezon. S. C. Yağcı Aksel (Ed.), Beyaz Camın Yerlileri (s. 13-52). Umuttepe. 